\title{
Spontaneous Glutamate Release Is Independent of Calcium Influx and Tonically Activated by the Calcium-Sensing Receptor
}

\author{
Nicholas P. Vyleta and Stephen M. Smith \\ Division of Pulmonary and Critical Care Medicine, Oregon Health \& Science University, Portland, Oregon 97239
}

\begin{abstract}
Spontaneous release of glutamate is important for maintaining synaptic strength and controlling spike timing in the brain. Mechanisms regulating spontaneous exocytosis remain poorly understood. Extracellular calcium concentration $\left(\left[\mathrm{Ca}^{2+}\right]_{0}\right)$ regulates $\mathrm{Ca}^{2+}$ entry through voltage-activated calcium channels (VACCs) and consequently is a pivotal determinant of action potential-evoked vesicle fusion. Extracellular $\mathrm{Ca}^{2+}$ also enhances spontaneous release, but via unknown mechanisms. Here we report that external Ca ${ }^{2+}$ triggers spontaneous glutamate release more weakly than evoked release in mouse neocortical neurons. Blockade of VACCs has no effect on the spontaneous release rate or its dependence on $\left[\mathrm{Ca}^{2+}\right]_{0}$. Intracellular $\left[\mathrm{Ca}^{2+}\right]$ slowly increases in a minority of neurons following increases in $\left[\mathrm{Ca}^{2+}\right]_{0}$. Furthermore, the enhancement of spontaneous release by extracellular calcium is insensitive to chelation of intracellular calcium by BAPTA. Activation of the calcium-sensing receptor (CaSR), a G-protein-coupled receptor present in nerve terminals, by several specific agonists increased spontaneous glutamate release. The frequency of spontaneous synaptic transmission was decreased in CaSR mutant neurons. The concentration-effect relationship for extracellular calcium regulation of spontaneous release was well described by a combination of CaSR-dependent and CaSR-independent mechanisms. Overall these results indicate that extracellular $\mathrm{Ca}^{2+}$ does not trigger spontaneous glutamate release by simply increasing calcium influx but stimulates CaSR and thereby promotes resting spontaneous glutamate release.
\end{abstract}

\section{Introduction}

Neurotransmitter release from a single vesicle activates a small postsynaptic voltage change and comprises the elementary unit of synaptic communication (Fatt and Katz, 1950; Del Castillo and Katz, 1954). Vesicle fusion is triggered by calcium entry through presynaptic voltage-activated calcium channels (VACCs) or may occur spontaneously in the absence of an action potential (Elmqvist and Feldman, 1965a; Llinás et al., 1976) Mechanisms controlling action potential-evoked and spontaneous exocytosis have been considered equivalent, with the intracellular $\left[\mathrm{Ca}^{2+}\right]$ $\left(\left[\mathrm{Ca}^{2+}\right]_{\mathrm{i}}\right)$ determining the rate of vesicle release (Del Castillo and Katz, 1954; Lou et al., 2005). However, mounting evidence suggests that two mechanistically distinct forms of release may exist. At central synapses, evoked and spontaneous release have been distinguished by differences in vesicle pools used, intracellular

\footnotetext{
Received Dec. 8, 2010; revised Feb. 1, 2011; accepted Feb. 6, 2011.

The work was supported by the National Institutes of Health and the Oregon Health \& Science University President's Fund. N.P.V. was supported by Training Grant T32HL033808 from the National Heart, Lung, and Blood Institute. We thank Drs. Xiaohua Wang and Wenyan Chen for assistance and advice, Drs. M. C. Andresen, H. von Gersdorff, and G. L. Westbrook for helpful comments, Drs. J.G. Seidman and D. Connor for providing the CaSR mutant mice, and Drs. M. Ruat, P. Dauban, and R. H. Dodd for providing Calindol. The content is solely the responsibility of the authors and does not necessarily represent the official views of the National Heart, Lung, and Blood Institute or the National Institutes of Health.

Correspondence should be addressed to Dr. Stephen M. Smith, Division of Pulmonary and Critical Care Medicine, 3181, SW Sam Jackson Park Road, UHN-67, 0.H.S.U., Portland, OR 97239. E-mail: smisteph@ohsu.edu.

N. P. Vyleta's present address: Institute of Science and Technology (IST) Austria, Am Campus 1, A-3400 Klosterneuburg, Austria.

DOI:10.1523/JNEUROSCI.6398-10.2011

Copyright $\odot 2011$ the authors $\quad 0270-6474 / 11 / 314593-14 \$ 15.00 / 0$
}

$\mathrm{Ca}^{2+}$ sensors for exocytosis, sensitivity to phorbol esters, the spatial separation of the postsynaptic receptors that they target, and by the mechanism by which endocytosis occurs (Sara et al., 2005; Virmani et al., 2005; Atasoy et al., 2008; Fredj and Burrone, 2009; Chung et al., 2010; Groffen et al., 2010). The central role of calcium as a trigger for exocytosis and the number of apparent differences between evoked and spontaneous release raises the question: are both forms of release regulated similarly by external calcium?

Evoked and spontaneous vesicle fusion are both sensitive to changes in extracellular $\left[\mathrm{Ca}^{2+}\right]\left(\left[\mathrm{Ca}^{2+}\right]_{\mathrm{o}}\right)$ (Elmqvist and Feldman, 1965b; Katz and Miledi, 1965). Evoked release is steeply dependent on $\left[\mathrm{Ca}^{2+}\right]_{0}$ at many synapses (Dodge and Rahamimoff, 1967; Augustine and Charlton, 1986; Borst and Sakmann, 1996; Reid et al., 1998; Rozov et al., 2001; Ikeda et al., 2008) and is usually triggered by $\mathrm{Ca}^{2+}$ entry via N-, P/Q-, or R-type VACCs (Wheeler et al., 1994; Jun et al., 1999; but see Momiyama and Takahashi, 1994). Release can be triggered by only 1 or 2 VACCs per vesicle (Augustine et al., 1991; Stanley, 1993; Shahrezaei et al., 2006; Bucurenciu et al., 2010), providing a mechanism by which stochastic activation of VACC could trigger spontaneous release.

We examined the mechanisms by which changes in $\left[\mathrm{Ca}^{2+}\right]_{0}$ mediate changes in spontaneous release by imaging $\left[\mathrm{Ca}^{2+}\right]_{\mathrm{i}}$ in nerve terminals and measuring miniature EPSCs (mEPSCs) in cultured neocortical neurons. The enhancement of mEPSC frequency by extracellular $\mathrm{Ca}^{2+}$ was not mediated by VACC, was insensitive to intracellular $\mathrm{Ca}^{2+}$ chelation by the exogenous buffer BAPTA, and was not caused by the reversal of the $\mathrm{Na}^{+}-\mathrm{Ca}^{2+}$ exchanger (NCX). Moreover, mEPSC frequency had a relatively 
low-order dependence on $\left[\mathrm{Ca}^{2+}\right]_{\mathrm{o}}$ and, surprisingly, was enhanced by extracellular $\mathrm{Mg}^{2+}$. Stimulation of a G-proteincoupled receptor (GPCR), the calcium-sensing receptor (CaSR), with specific agonists increased mEPSC frequency, and CaSR loss-of-function mutant neurons had fewer spontaneous events over the physiological range of $\left[\mathrm{Ca}^{2+}\right]_{\mathrm{o}}$. These data indicate that extracellular $\mathrm{Ca}^{2+}$ enhances spontaneous glutamate release differently than it does action potential-evoked release, and suggest that $\mathrm{Ca}^{2+}$ in the synaptic cleft can promote spontaneous exocytosis by activation of a presynaptic GPCR.

\section{Materials and Methods}

Neuronal preparation. Neocortical neurons were isolated from male and female postnatal day 1 (P1)-P2 $\mathrm{CaSR}^{+/+}$or $\mathrm{CaSR}^{-/-}$(Ho et al., 1995) mouse pups. All animal procedures were approved by Oregon Health \& Science University's Institutional Animal Care and Use Committee in accordance with the U.S. Public Health Service Policy on Humane Care and Use of Laboratory Animals and the National Institutes of Health Guide for the Care and Use of Laboratory Animals. Animals were deeply anesthetized with isoflurane before decapitation and removal of cortices. Cortices were then incubated in trypsin and DNase and then dissociated with a heat polished pipette. Dispersed cells were cultured in MEM plus 5\% FBS on glass coverslips. Cytosine arabinoside $(4 \mu \mathrm{M})$ was added $48 \mathrm{~h}$ after plating to limit glial division. Cells were used after at least $14 \mathrm{~d}$ in culture.

Genotyping CaSR mutant mice. Heterozygotes for the CaSR mutation were mated to produce $\mathrm{CaSR}^{-1-}$ as this mutation is lethal at P3-P30. DNA from mouse tail was released by treatment with $50 \mathrm{~mm} \mathrm{NaOH}$ at $95^{\circ} \mathrm{C}$ for $15 \mathrm{~min}$, followed by the addition of $1 \mathrm{~m}$ Tris, $\mathrm{pH} 8.0$, and $10 \mathrm{~mm}$ EDTA. PCR was then performed using DNA solution and three primers: CaSR 5': TCTCTTCTCTTTAGGTCCTGAAAGA, CaSR 3': TCATTGATGAACAGTCTTTCTCCCT, and r-neo2: TCTTGATTCCCACTTTGTCCTTGTA. The samples were run on a $1 \%$ agarose gel and identified as $\mathrm{CaSR}^{+/+}, \mathrm{CaSR}^{+/-}$, or $\mathrm{CaSR}^{-1-}$.

Electrophysiological recordings. Cells were visualized with an Olympus IX70 inverted microscope. Recordings were made in whole-cell voltageclamp mode. Holding potential was $-70 \mathrm{mV}$ corrected for liquidjunction potentials. Extracellular solutions contained the following (in mM): $150 \mathrm{NaCl}, 4 \mathrm{KCl}, 10$ HEPES, 10 glucose, $\mathrm{pH}$ 7.35. For high $\left[\mathrm{Ca}^{2+}\right]_{\mathrm{o}}$ and $\left[\mathrm{Mg}^{2+}\right]_{\mathrm{o}}$ experiments, $\mathrm{NaCl}$ was reduced to maintain osmolarity. Recordings of mEPSCs were made in the presence of tetrodotoxin (TTX) $(1-2 \mu \mathrm{M})$ and bicuculline (Bic) $(10 \mu \mathrm{M})$ to block $\mathrm{Na}^{+}$channels and GABA-activated currents, respectively. For recordings of evoked EPSCs, bicuculline $(10 \mu \mathrm{M})$ was used to block inhibitory transmission. Both potassium gluconate and cesium methane-sulfonate containing intracellular solutions were used. Potassium gluconate solution consisted of the following (in mM): $113 \mathrm{~K}^{+}$gluconate, 9 EGTA, $10 \mathrm{HEPES}, 4 \mathrm{MgCl}_{2}, 1$ $\mathrm{CaCl}_{2}, 4 \mathrm{NaATP}, 0.3 \mathrm{NaGTP}, 14$ creatine phosphate, $\mathrm{pH}$ 7.2. Cesium methane-sulfonate solution consisted of the following (in mM): $108 \mathrm{Cs}^{+}$ methane-sulfonate, 9 EGTA, 10 HEPES, $4 \mathrm{MgCl}_{2}, 1 \mathrm{CaCl}_{2}$, $4 \mathrm{NaATP}, 0.3$ $\mathrm{NaGTP}, 14$ creatine phosphate, $\mathrm{pH}$ 7.2. Electrodes had resistances of 3-7 $\mathrm{M} \Omega$. Currents were recorded with a HEKA EPC $9 / 2$ amplifier. For mEPSC recordings, currents were filtered at $1 \mathrm{kHz}$ using a Bessel filter and sampled at $10 \mathrm{kHz}$. Series resistance $\left(R_{\mathrm{s}}\right)$ was monitored, and recordings were discarded if $R_{\mathrm{s}}$ changed significantly during the course of a recording. $R_{\mathrm{s}}$ compensation was set to $60-70 \%$ in many recordings of $\mathrm{mEPSC}$ frequency. In VACC and evoked EPSC recordings, currents were filtered at $3 \mathrm{kHz}$, sampled at $20 \mathrm{kHz}$, and $R_{\mathrm{s}}$ was compensated by $\geq 70 \%$.

EPSCs were evoked using a theta stimulating electrode connected to a high-voltage stimulus isolator (World Precision Instruments, product \#A365D). Theta glass was pulled to a tip of $\sim 5 \mu \mathrm{m}$ outer diameter and filled with extracellular solution. The electrode was positioned near to putative axons abutting the postsynaptic cell and stimulus intensity adjusted (0.3-0.5 mA, $0.1 \mathrm{~ms}$ duration) until EPSCs were recorded.

Imaging. Single neurons were filled with fluorescent dye. After forming a whole-cell configuration, neurons were voltage-clamped for 10-20 min to load the neuron with fluorescent dyes. The patch pipette was then carefully retracted and optical recordings performed. Recordings were made using an EGTA- and $\mathrm{Ca}^{2+}$-free $\mathrm{K}^{+}$gluconate-rich $(118 \mathrm{~mm})$ pipette solution. The pipette solution also contained Alexa Red 594 (40 $\mu \mathrm{M}$, Invitrogen) for visualization of cell morphology (Yu et al., 2010) and a green $\mathrm{Ca}^{2+}$ indicator Fluo-4 [(2-\{[2-(2-\{5-[bis(carboxymethyl)amino]-2-methylphenoxy\}ethoxy)4-(2,7-difluoro-6-hydroxy-3-oxo-3H-xanthen-9-yl)phenyl] (carboxymethyl)amino\}acetic acid)), $100 \mu \mathrm{M}$, Invitrogen], or Oregon Green BAPTA-1 $\left[(\mathrm{OGB} 1), 200 \mu \mathrm{M}\right.$, Invitrogen] for detection of changes in $\left[\mathrm{Ca}^{2+}\right]_{\mathrm{i}}$ (Schipke et al., 2001). Cells were visualized using a 1.2 numerical aperture $60 \times$ waterimmersion objective (Olympus America) and cooled CCD camera (Orca, Hamamatsu) with computer controlled shutter. Alexa Red fluorescence was captured using the following filters: 542-582 nm excitation, 530-585/601$800 \mathrm{~nm}$ (reflect/transmit) dichroic, and 604-644 nm emission. Fluo-4 and OGB1 fluorescence was captured using the following filters: $470-490 \mathrm{~nm}$ excitation, 446-500/514-725 nm dichroic, and 505-545 nm emission.

Solutions. Solutions were gravity fed through a $1.2 \mathrm{~mm}$ outer diameter glass capillary placed $\sim 1 \mathrm{~mm}$ from the patch pipette tip. KB-R7943 (2[2-[4-(4-nitrobenzyloxy)phenyl] ethyl] isothiourea mesylate; Tocris Biosciences) was dissolved in DMSO at $50 \mathrm{~mm}$ stock concentration and used at 1:10,000 dilution. Calindol and cinacalcet (Toronto Research Chemicals) were dissolved in ethanol at $10 \mathrm{~mm}$ stock concentration and used at 1:2000 dilution. BAPTA-AM (Invitrogen) was dissolved in DMSO at 50 or $100 \mathrm{~mm}$ stock concentration and diluted 1:1000. To ensure BAPTA-AM dissolved completely, before use extracellular solution were incubated at $30^{\circ} \mathrm{C}$ while undergoing ultrasonic agitation for $\sim 30 \mathrm{~min}$.

Analysis. Data were acquired on a PIII computer and analyzed with IgorPro (Wavemetrics) and Minianalysis (Synaptosoft) software. mEPSC data were normalized to the average mEPSC frequency during at least $100 \mathrm{~s}$ of recording in baseline $\left[\mathrm{Ca}^{2+}\right]_{\mathrm{o}}$ and $\left[\mathrm{Mg}^{2+}\right]_{\mathrm{o}}$ (both $1.1 \mathrm{~mm}$ ) unless otherwise noted. For individual recordings in which $\mathrm{mEPSC}$ frequency desensitization was visible the peak $30 \mathrm{~s}$ of data was averaged ( $10 \mathrm{~s}$ bins). Otherwise, steadystate $\mathrm{mEPSC}$ frequency changes were measured. Statistical significance was determined using Student's $t$ test or Mann-Whitney test as appropriate (Microsoft EXCEL; GraphPad Prism). p-values $<0.05$ were considered significant. Data values are reported as mean \pm SEM.

Fluorescence data were analyzed using Wasabi software (Hamamatsu Photonics). Fluorescent regions of interest were defined manually. For analysis of nerve terminal $\mathrm{Ca}^{2+}$ indicator fluorescence signals, small elliptical regions of interest were drawn around the outside of putative synaptic boutons and maximum intensity analyzed over time. These signals were averaged over all boutons for an individual neuron and those single neuron averages combined to produce average diary plots (see Fig. $5 E)$. Background fluorescence was averaged and subtracted.

Extracellular stimulus-evoked charge transfer (see Fig. $6 D$ ) was calculated as the integral of the stimulus-evoked currents (see Fig. 6C). EPSC duration was determined by visual inspection, and currents were integrated for an average of $13 \mathrm{~ms}$ following stimulus artifact. For the representative recording shown below in Figure 6C, currents were integrated for $10 \mathrm{~ms}$.

Curve fitting was performed using IgorPro. VACC conductance $(G)$ was calculated by transforming VACC currents using the equation:

$$
G=I /\left(V-V_{\text {rev }}\right),
$$

where $I$ and $V$ are the membrane current and potential, respectively. Reversal potentials $\left(V_{\text {rev }}\right)$ were estimated by extrapolating the linear portion of the current traces to zero. Plots of conductance versus $V_{\mathrm{m}}$ were fit with the Boltzmann function, $G=G_{\max } /\left(1+e^{\left.\left(V_{1 / 2}-V\right) / k\right)}\right)$, where $G_{\max }$ is maximal conductance, $V_{1 / 2}$ is half-maximal activation voltage, and $k$ is the slope factor.

Miniature EPSC frequency versus $\left[\mathrm{Ca}^{2+}\right]_{\mathrm{o}}$ for $\mathrm{CaSR}^{-1-}$ data were fit with a power function of the form:

$$
y=y_{\mathrm{o}}+A x^{z},
$$

where $y$ equals the mEPSC frequency at $\left[\mathrm{Ca}^{2+}\right]_{\mathrm{o}}$ of $x, y_{\mathrm{o}}$ is the base of the curve, $z$ is the exponent, and $A$ is the coefficient.

$\mathrm{CaSR}^{+/+}$data were described using the sum of the power function (1) and a Hill equation of the form:

$$
y=y_{\max } /\left[1+\left(\mathrm{EC}_{50} / x\right)^{n}\right]
$$

where $y_{\max }$ is the maximum mEPSC frequency attributed to activation by CaSR and $n$ is the Hill coefficient. 


\section{Results}

Extracellular $\mathrm{Ca}^{2+}$ enhances spontaneous vesicle fusion

We made whole-cell patch-clamp recordings from neocortical neurons voltage-clamped at $-70 \mathrm{mV}$. To investigate the effect of varying $\left[\mathrm{Ca}^{2+}\right]_{\mathrm{o}}$ on the spontaneous vesicle fusion rate, we measured mEPSCs when neuronal firing was blocked with tetrodotoxin $(1 \mu \mathrm{M})$. Bicuculline methiodide $(10 \mu \mathrm{M})$ was present in all external solutions to block $\mathrm{GABA}_{\mathrm{A}}$ receptor-mediated postsynaptic currents. Increasing extracellular $\mathrm{Ca}^{2+}$ reversibly increased mEPSC frequency (Fig. $1 A, B$ ). The concentration-effect relationship for mEPSC frequency versus $\left[\mathrm{Ca}^{2+}\right]_{0}$ did not saturate even when $\left[\mathrm{Ca}^{2+}\right]_{\mathrm{o}}$ was increased to $20 \mathrm{~mm}$ (Fig. $1 C$ ). Furthermore, the relationship was approximately linear on a double logarithmic plot with a slope of 0.63 , which is substantially lower than $\sim 4$ reported for evoked transmission (Dodge and Rahamimoff, 1967; Augustine and Charlton, 1986; Borst and Sakmann, 1996; Reid et al., 1998; Rozov et al., 2001; Ikeda et al., 2008). One possible explanation for the reduced steepness of the concentration-effect relationship is that the sustained application of high $\left[\mathrm{Ca}^{2+}\right]$ desensitized the spontaneous release process (Fig. 1). We tested for desensitization by making single step changes in $\left[\mathrm{Ca}^{2+}\right]_{\mathrm{o}}$. As expected a step change in $\left[\mathrm{Ca}^{2+}\right]_{\mathrm{o}}$ from 1.1 to $6 \mathrm{mM}$ increased mEPSC frequency (Fig. $2 A$ ). The time courses of the changes in mEPSC frequency were described by monoexponential functions following step changes in $\left[\mathrm{Ca}^{2+}\right]_{\mathrm{o}}$ from $1.1 \mathrm{~mm}$ to the range $0.2-20 \mathrm{~mm}$ (Fig. $2 \mathrm{~B}$ ). The concentration-effect curve for mEPSC frequency versus $\left[\mathrm{Ca}^{2+}\right]_{0}$ following single step changes in $\left[\mathrm{Ca}^{2+}\right]_{\mathrm{o}}$ was unchanged compared with the multistep protocol over the lower part of the range (Fig. 2C, solid circles). However, the slope increased to 1.1 when $\left[\mathrm{Ca}^{2+}\right]_{\mathrm{o}}>2 \mathrm{mM}$, suggesting spontaneous release may have been desensitized by higher $\left[\mathrm{Ca}^{2+}\right]_{\mathrm{o}}$ (Fig. $2 \mathrm{C}$ ). Overall the concentration-effect relationship for spontaneous release was much less steep than for evoked release suggesting that external $\mathrm{Ca}^{2+}$ regulates spontaneous and evoked release by distinct mechanisms (Dodge and Rahamimoff, 1967; Augustine and Charlton, 1986; Borst and Sakmann, 1996; Reid et al., 1998; Rozov et al., 2001; Ikeda et al., 2008).

Extracellular $\mathrm{Ca}^{2+}$ reversibly decreased mEPSC amplitude in a dose-dependent manner (Fig. 2D-G), presumably resulting from the reduced electrochemical gradient for $\mathrm{Na}^{+}$influx through glutamate receptors following the substitution of extracellular $\mathrm{Na}^{+}$by $\mathrm{Ca}^{2+}$ (osmolarity kept constant).

\section{mEPSC frequency increase is not an artifact of altered detection of postsynaptic events}

Since divalent cations screen surface charges, shift ion channel gating, and thereby reduce membrane excitability (Hille, 2001), we hypothesized that elevation of $\left[\mathrm{Ca}^{2+}\right]_{\mathrm{o}}$ right-shifted channel activation, and thereby increased input resistance and extended the space-clamp of the postsynaptic neuronal membrane, enhancing mEPSC detection from distal sites resulting in an apparent increase in mEPSC frequency. However, input resistance at the soma $\left(R_{\text {in }}\right)$ was relatively insensitive to increases in $\left[\mathrm{Ca}^{2+}\right]_{0}$ from 1.1 to $6 \mathrm{mM}$. Average $R_{\text {in }}$ (calculated from steady-state current following $-5 \mathrm{mV}$ step) was $188 \pm 0.90$ and $196 \pm 17 \mathrm{M} \Omega$ in 1.1 and $6 \mathrm{~mm}$ extracellular $\mathrm{Ca}^{2+}$, respectively $(p=0.72, n=3$, data not shown). Thus it is extremely unlikely that the average fourfold increase in mEPSC frequency we recorded under these conditions arose from these modest changes in $R_{\mathrm{in}}$. Moreover the rise and decay times for the mEPSCs were slightly decreased rather than prolonged, as expected if they had arisen from distant sites (average 10-90\% rise time decreased from $0.90 \pm 0.14$ to $0.86 \pm 0.15 \mathrm{~ms}$ and the average decay time constant decreased
A

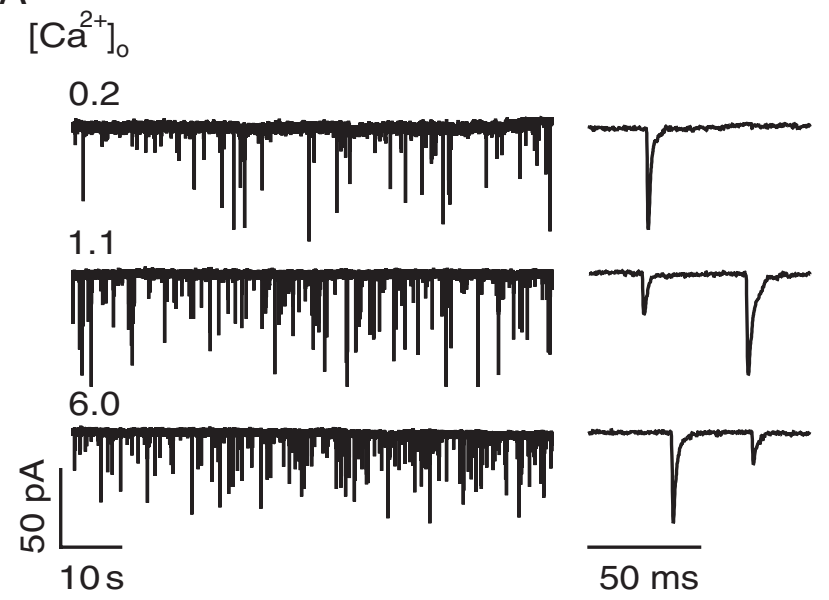

$\mathrm{B}$
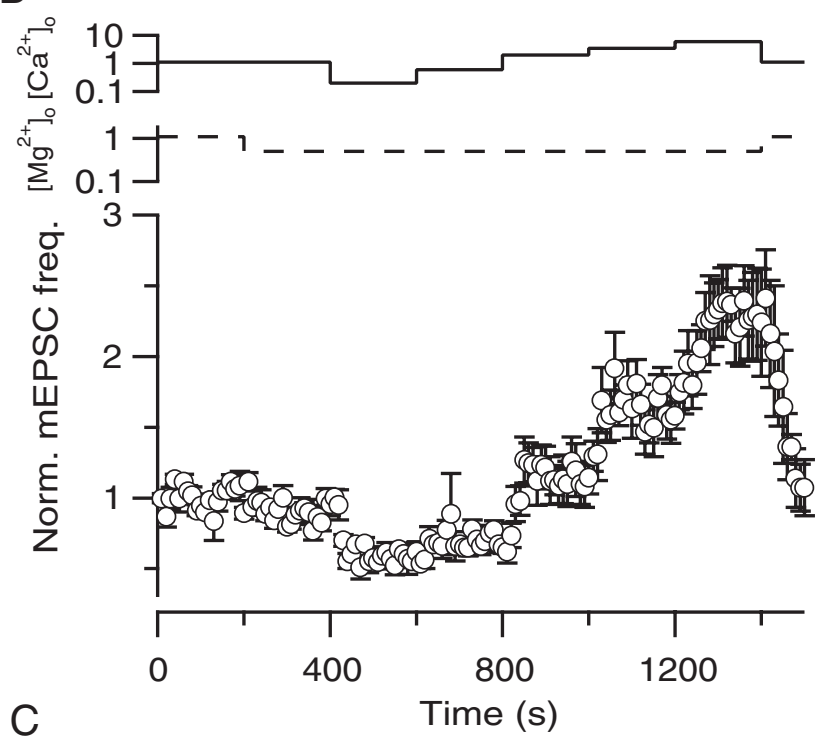

C

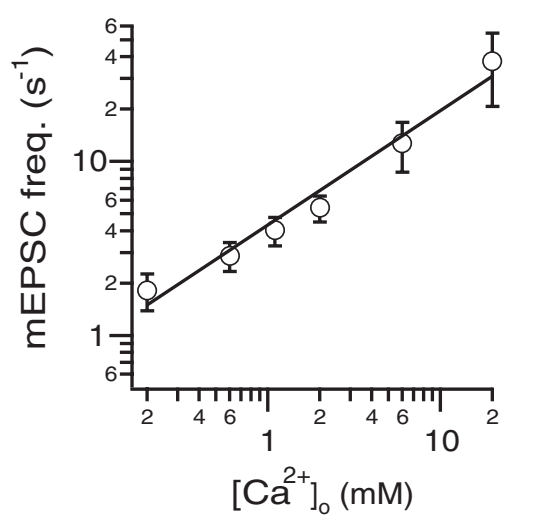

Figure 1. Spontaneous vesicle fusion is enhanced by extracellular $\mathrm{Ca}^{2+} . \boldsymbol{A}$, Recording of mEPSCs in whole-cell voltage clamp in the presence of TTX (1 $\mu \mathrm{M})$ and bicuculline (10 $\mu \mathrm{M})$. $\mathrm{mEPSC}$ frequency increased with $\left[\mathrm{Ca}^{2+}\right]_{0}$ (indicated on left in $\mathrm{mM}$ ). $\left[\mathrm{Mg}^{2+}\right]_{0}$ was 0.5 $\mathrm{mm}$ for these recordings. $\boldsymbol{B}$, Average normalized plot of mEPSC frequency versus time showing that sequential step changes in $\left[\mathrm{Ca}^{2+}\right]_{0}$ dose-dependently and reversibly modulated mEPSC frequency $(n=5)$. $\left[\mathrm{Ca}^{2+}\right]_{0}$ was increased stepwise from 0.2 to $6 \mathrm{~mm}$ (solid line) and $\left[\mathrm{Mg}^{2+}\right]_{0}$ kept at $1.1 \mathrm{~mm}$ or $0.5 \mathrm{~mm}$ (broken line). C, Concentration- effect curve for mEPSC frequency versus $\left[\mathrm{Ca}^{2+}\right]_{0}$. mEPSC frequency was $1.8 \pm 0.43,2.9 \pm 0.55$, $4.0 \pm 0.75,5.4 \pm 0.92,13 \pm 4.1$, and $38 \pm 17 \mathrm{~s}^{-1}$ for $\left[\mathrm{Ca}^{2+}\right]_{0}=0.2,0.6,1.1,2,6$, and $20 \mathrm{~mm}(n=8,11,10,11,11$, and 3 , respectively). 
from $3.5 \pm 0.53$ to $3.2 \pm 0.52$ upon elevation of $\left[\mathrm{Ca}^{2+}\right]_{\mathrm{o}}, p=0.02$ and 0.05 , respectively, data not shown). Thus, the changes in mEPSC frequency that accompanied the change in bath $\left[\mathrm{Ca}^{2+}\right]$ were not explained by altered detection of postsynaptic events.

VACC-mediated $\mathrm{Ca}^{2+}$ influx does not mediate extracellular $\mathrm{Ca}^{2+}$ enhancement of spontaneous fusion Previous investigations have proposed that changes in $\left[\mathrm{Ca}^{2+}\right]_{\text {o }}$ produce changes in $\left[\mathrm{Ca}^{2+}\right]_{\mathrm{i}}$ and thus the rate of spontaneous release (Xu et al., 2009). An allosteric model of vesicle fusion rate versus $\left[\mathrm{Ca}^{2+}\right]_{\mathrm{i}}$ predicts that spontaneous release is a consequence of intracellular $\mathrm{Ca}^{2+}$ binding to the $\mathrm{Ca}^{2+}$ sensor for calcium-mediated exocytosis, and that this relationship has a low $\mathrm{Ca}^{2+}$ dependence over the range of resting $\left[\mathrm{Ca}^{2+}\right]_{\mathrm{i}}$ (Lou et al., 2005). We hypothesized that stochastic activation of VACCs produced increases in $\left[\mathrm{Ca}^{2+}\right]_{i}$, and that these events resulted in spontaneous exocytosis more frequently when the driving force for $\mathrm{Ca}^{2+}$-influx was increased by elevation of $\left[\mathrm{Ca}^{2+}\right]_{\mathrm{o}}$. To test this hypothesis we measured the extracellular $\mathrm{Ca}^{2+}$ dependence of mEPSC frequency in the presence of the VACC blocker, cadmium $\left(\mathrm{Cd}^{2+}, 100 \mu \mathrm{M}\right)$ (Carbone et al., 1997; Chen et al., 2007). $\mathrm{Cd}^{2+}$ did not decrease mEPSC frequency at baseline $(1.1 \mathrm{~mm})$ or elevated $(6 \mathrm{~mm})$ $\left[\mathrm{Ca}^{2+}\right]_{\mathrm{o}}$ (Fig. $3 \mathrm{~A}, \mathrm{~B}$ ). Elevation of $\left[\mathrm{Ca}^{2+}\right]_{\mathrm{o}}$ to $6 \mathrm{~mm}$ also increased mEPSC frequency after pretreatment with $\mathrm{Cd}^{2+}$ (Fig. 3C). Both the magnitude and time course of mEPSC frequency enhancement by extracellular $\mathrm{Ca}^{2+}$ were unchanged by $\mathrm{Cd}^{2+}$ (Fig. 3D, E) (see also Abenavoli et al., 2002). We confirmed that $\mathrm{Cd}^{2+}$ blocked somatic VACC currents in these cultured neocortical neurons (Fig. 3F). Application of $\omega$-conotoxin MVIIC $(5 \mu \mathrm{M})$, which blocks $\mathrm{N}$ - and P/Q-type VACCs in cortical neurons (Hillyard et al., 1992; Rozov et al., 2001), also had no effect on the enhancement of mEPSC frequency when stepping extracellular $\mathrm{Ca}^{2+}$ from 1.1 to $6 \mathrm{~mm}(8.0 \pm$ 3.2-fold enhancement, $n=2$, data not shown). Together these data strongly indicate that VACC-mediated $\mathrm{Ca}^{2+}$ influx is not the trigger for spontaneous vesicle fusion at baseline $\left[\mathrm{Ca}^{2+}\right]_{0}$ or elevated $\left[\mathrm{Ca}^{2+}\right]_{\text {. }}$.

$\mathrm{Na}^{+} / \mathrm{Ca}^{2+}$ exchange regulates baseline spontaneous release but does not mediate extracellular $\mathrm{Ca}^{2+}$ enhancement

$\mathrm{Na}^{+}-\mathrm{Ca}^{2+}$ exchange has been shown to play a prominent role in the removal of
A

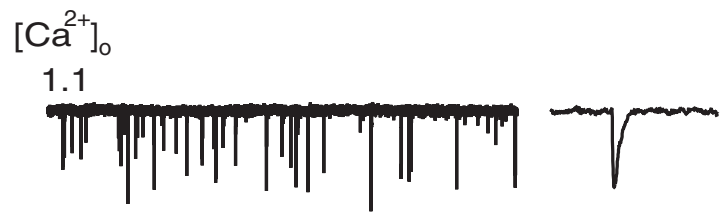

6.0
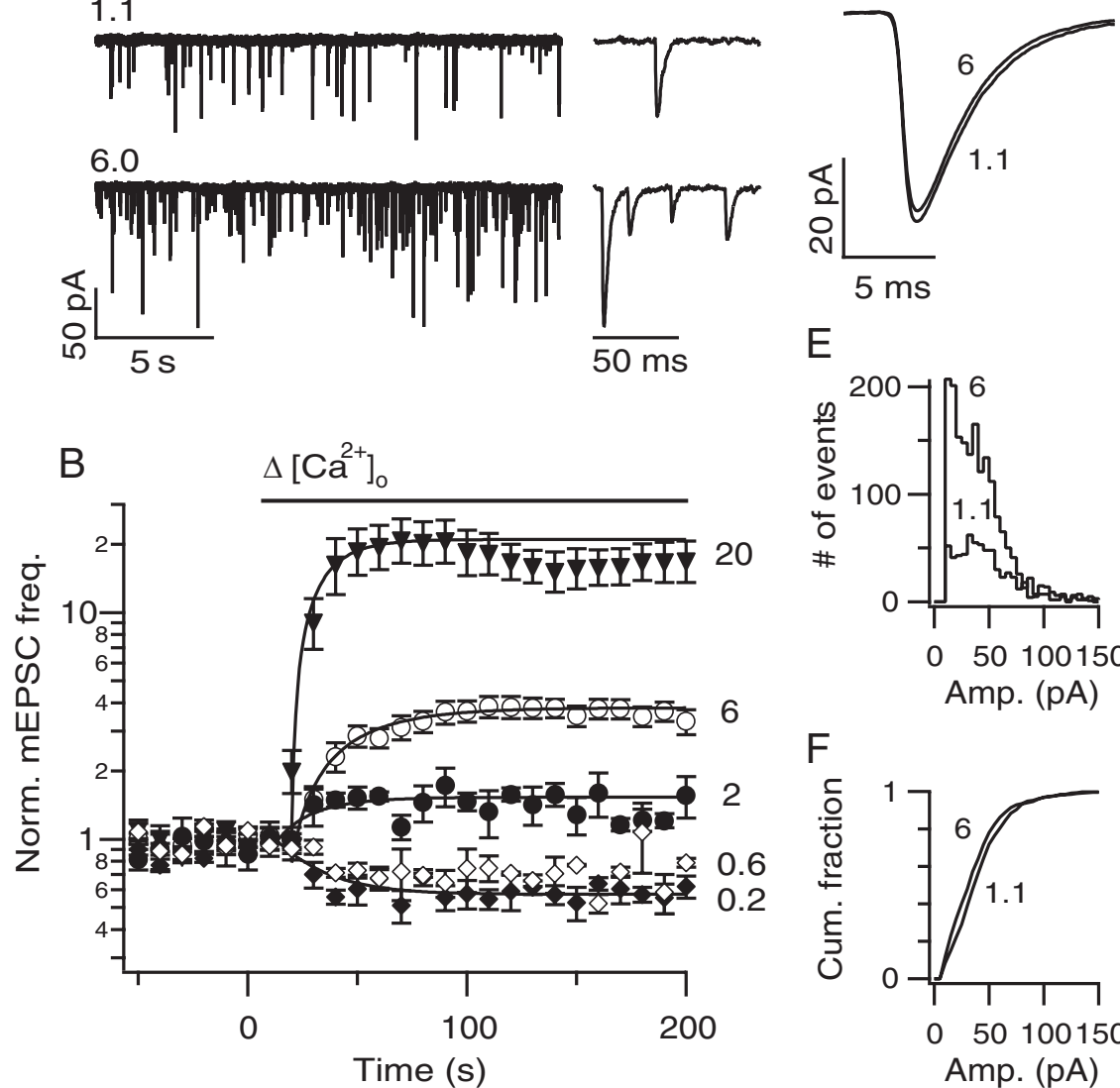

$\mathrm{E}$

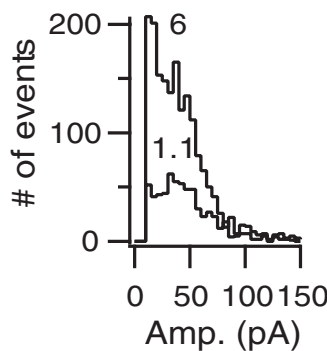

$\mathrm{F}$

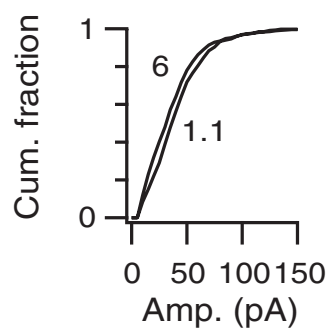

C

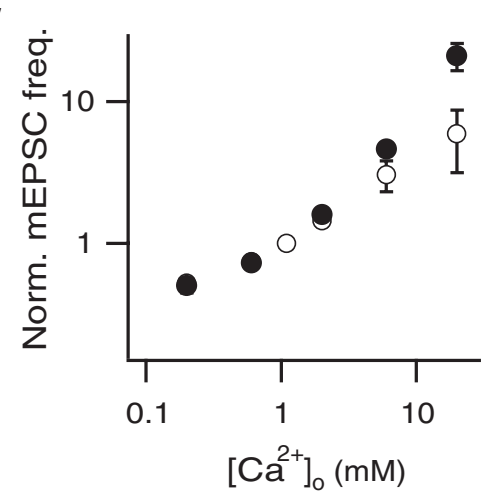

G

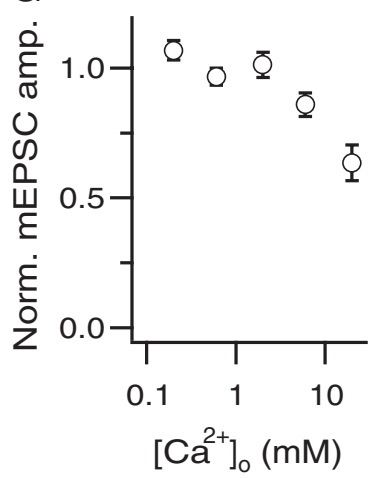

Figure 2. mEPSC frequency and amplitude dependence on $\left[\mathrm{Ca}^{2+}\right]_{0}$. $A$, Representative traces show that a single-step change in $\left[\mathrm{Ca}^{2+}\right]_{0}$ from 1.1 (top) to $6 \mathrm{~mm}$ (bottom) increased mEPSC frequency. $\left[\mathrm{Mg}^{2+}\right]_{0}=0.5 \mathrm{~mm}$ for these recordings. $\boldsymbol{B}$, Diary plots of mEPSC frequency versus time show changes in mEPSC frequency in response to changing $\left[\mathrm{Ca}^{2+}\right]_{0}$ from 1.1 to concentrations indicated on the right (in $\mathrm{mm}$ ). Data points were normalized to average mEPSC frequency in $1.1 \mathrm{~mm}\left[\mathrm{Ca}^{2+}\right]_{0}$ during 100 s preceding $\left[\mathrm{Ca}^{2+}\right]_{0}$ change. $n=5,2,4,14$, and 5 for steps to $0.2,0.6,2.0,6.0$ and $20 \mathrm{~mm}$, respectively. Diary plots were well described by

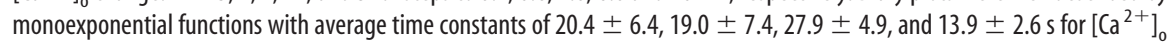
changes to $0.2,2,6$, and $20 \mathrm{~mm}$, respectively. $C$, Normalized concentration- effect curves for mEPSC frequency versus $\left[\mathrm{Ca}^{2+}\right]_{0}$ from experiment in $\boldsymbol{B}$ (closed circles) and from data shown in Figure $1 C$ (open circles). Curve generated from single-step $\left[\mathrm{Ca}^{2+}\right]_{0}$ change experiment is slightly steeper for higher $\mathrm{Ca}^{2+}$ concentrations than curve generated by experiments in Figure 1. and neither curve saturates. $\boldsymbol{D}$, Average mEPSCs in control $(1.1 \mathrm{~mm})$ and elevated $\left[\mathrm{Ca}^{2+}\right]_{0}(6 \mathrm{~mm})$ for representative recording in $\boldsymbol{A}$. Traces are averages of 302 and 917 events for control and high $\left[\mathrm{Ca}^{2+}\right]_{0}$, respectively. $\boldsymbol{E}, \boldsymbol{F}$, Amplitude histograms of mEPSCs from recording in $\boldsymbol{A}$. Events from $200 \mathrm{~s}$ of recording in either $\left[\mathrm{Ca}^{2+}\right]_{0}$ are shown. Elevation of $\left[\mathrm{Ca}^{2+}\right]_{0}$ produced a small decrease in $\mathrm{mEPSC}$ amplitude. $\mathbf{G}$, Concentration- effect curve for average steady-state mEPSC amplitude versus $\left[\mathrm{Ca}^{2+}\right]_{0}$. All points normalized to average $m E P S C$ amplitude during $100 \mathrm{~s}$ of recording before $\left[\mathrm{Ca}^{2+}\right]_{0}$ was changed. Normalized mEPSC amplitude was $1.1 \pm 0.03$, $0.97 \pm 0.03,1.0 \pm 0.05,0.86 \pm 0.03$, and $0.64 \pm 0.07$ that of control for $0.2,0.6,2,6$, and $20 \mathrm{~mm}\left[\mathrm{Ca}^{2+}\right]_{0}(n=6,2,4,4$, and 5 , respectively). 
A
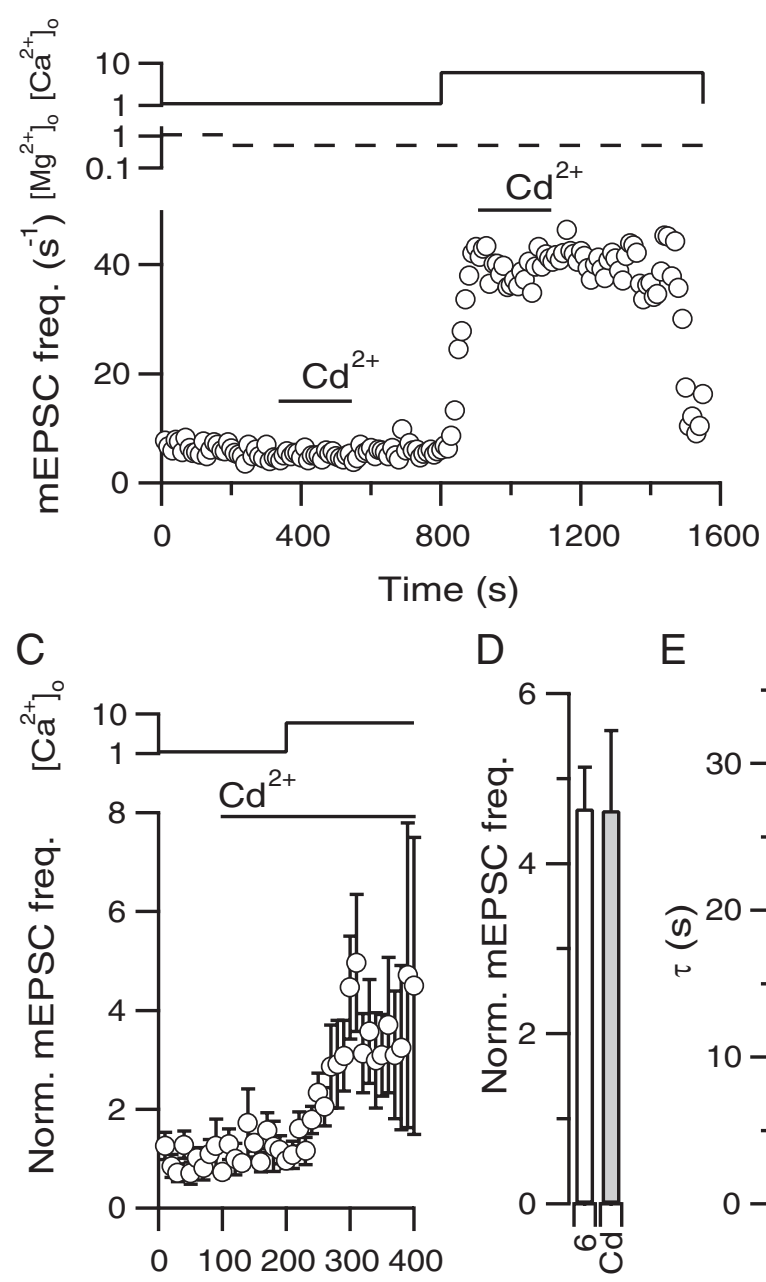

Time (s)
B

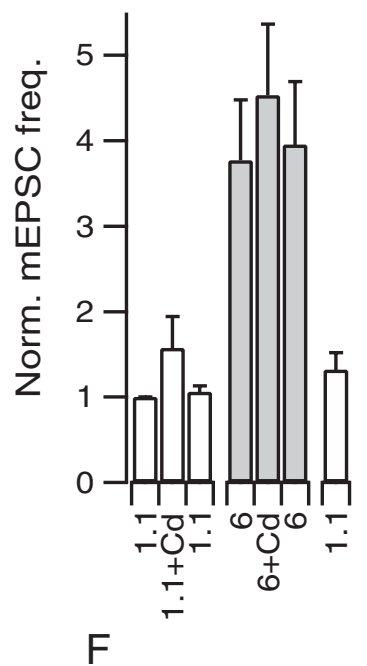

$\mathrm{D}$

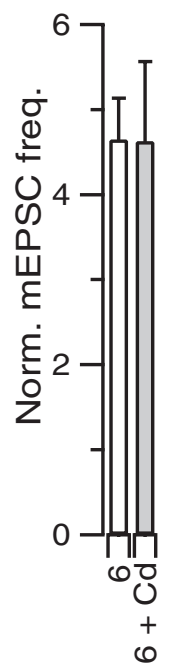

E

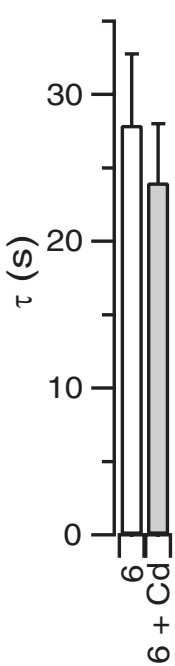

baseline and increasing $\left[\mathrm{Ca}^{2+}\right]_{0}$ following NCX inhibition further enhanced mEPSC frequency to $16.8 \pm 4.1$ times that of baseline (Fig. $4 B, C, p=0.03$ ). Interestingly, exponential fits of the average extracellular $\mathrm{Ca}^{2+}$-induced mEPSC frequency increases revealed that the rate of enhancement of spontaneous release by extracellular $\mathrm{Ca}^{2+}$ was twofold greater when NCX was blocked ( $\tau=17$ vs $9 \mathrm{~s}$ ).

Together these data indicate that NCX activity regulates baseline spontaneous fusion rate but that reversal of NCX does not mediate extracellular $\mathrm{Ca}^{2+}$ enhancement of spontaneous vesicle fusion. Furthermore, increasing baseline spontaneous vesicle fusion by inhibition of NCX enhanced the rate of facilitation of spontaneous release by elevation of $\left[\mathrm{Ca}^{2+}\right]_{0}$.

\section{Increases in $\left[\mathrm{Ca}^{2+}\right]_{\mathrm{o}}$ produce modest} increases in nerve terminal $\left[\mathrm{Ca}^{2+}\right]_{i}$ Next we tested whether slowly occurring changes in $\left[\mathrm{Ca}^{2+}\right]_{\mathrm{i}}$ could link extracellular $\mathrm{Ca}^{2+}$ and spontaneous vesicle fusion. Neurons were filled with green $\mathrm{Ca}^{2+}$ indicator (Fluo-4 or Oregon Green BAPTA-1) and red morphological dye (Alexa594). We identified nerve terminals by their characteristic punctate appearance, size, and tendency to occur as axonal swellings $>100 \mu \mathrm{m}$ from the soma [Fig. $5 \mathrm{~A}$, $\mathrm{T}$ (terminal) and inset] (Yu et al., 2010). These were distinguishable from the larger, more heterogeneous spines observed connected to dendrites and soma [Fig. 5A, $\mathrm{S}$ (spine) and inset]. Increasing $\left[\mathrm{Ca}^{2+}\right]_{0}$ from 1.1 to $6 \mathrm{~mm}$ did not increase Fluo-4 fluorescence, although a robust response to high external potassium $\left(\mathrm{K}^{+}, 90 \mathrm{~mm}\right)$ was measured in the same puncta (Fig. $5 B$ ). We hypothesized that extracellular $\mathrm{Ca}^{2+}$-induced changes in $\left[\mathrm{Ca}^{2+}\right]_{\mathrm{i}}$ were too small to be detected by Fluo-4, so we switched to the higher affinity $\mathrm{Ca}^{2+}$ indi-

$\mathrm{Ca}^{2+}$ from nerve terminals (Nachshen et al., 1986; SanchezArmass and Blaustein, 1987; Fontana et al., 1995). We hypothesized that if extracellular $\mathrm{Ca}^{2+}$ enhanced spontaneous fusion by promoting reverse-mode NCX activity $\left(\mathrm{Na}^{+}\right.$efflux, $\mathrm{Ca}^{2+}$ influx), then direct inhibition of NCX-mediated $\mathrm{Ca}^{2+}$ transport should block the enhancement of spontaneous fusion by elevation of $\left[\mathrm{Ca}^{2+}\right]_{\mathrm{o}}$. KB-R7943 inhibits forward- and reverse-mode NCX currents (Watano et al., 1996; Kimura et al., 1999). Basal mEPSC frequency was substantially increased by KB-R7943 (5 $\mu \mathrm{M}, 10 \mathrm{~min}$ application; Fig. $4 \mathrm{~A}$, top and middle traces) consistent with the hypothesis that NCX modulates basal $\left[\mathrm{Ca}^{2+}\right]_{\mathrm{i}}$ and spontaneous fusion. To test whether NCX is part of the pathway by which extracellular $\mathrm{Ca}^{2+}$ enhances spontaneous vesicle fusion, we elevated $\left[\mathrm{Ca}^{2+}\right]_{0}$ after NCX inhibition. Increasing $\left[\mathrm{Ca}^{2+}\right]_{\mathrm{o}}$ from 1.1 to $6 \mathrm{~mm}$ still produced a large increase in spontaneous fusion rate after KB-R7943 application (Fig. 4A,B). On average, KB-R7943 elevated mEPSC frequency to $9.8 \pm 1.9$ times cator OGB1 ( $K_{\mathrm{d}} \sim 345$ and $170 \mathrm{~nm}$, respectively) (Johnson and Spence, 2010). Unlike in the Fluo-4 experiments, application of TTX and Bic clearly reduced fluorescence (by 38\%) consistent with OGB1 being more sensitive to changes in basal $\left[\mathrm{Ca}^{2+}\right]_{\mathrm{i}}$ (Fig. $5 C$ ). Interestingly this indicates that ion channel activity regulates basal nerve terminal $\left[\mathrm{Ca}^{2+}\right]_{\mathrm{i}}$. Upon elevation of $\left[\mathrm{Ca}^{2+}\right]_{0}$, we observed two types of responses. In some neurons, nerve terminal $\left[\mathrm{Ca}^{2+}\right]_{i}$ was insensitive to elevation of $\left[\mathrm{Ca}^{2+}\right]_{\mathrm{o}}$ (Fig. $5 D$, left). Other neurons displayed increases in terminal OGB1 fluorescence on increases of $\left[\mathrm{Ca}^{2+}\right]_{\mathrm{o}}$ (Fig. $5 D$, right) consistent with the conclusion that neocortical neurons are heterogeneous in terms of their terminal $\left[\mathrm{Ca}^{2+}\right]_{\mathrm{i}}$ sensitivity to $\left[\mathrm{Ca}^{2+}\right]_{0}$. All recordings showed robust responses to high extracellular $\left[\mathrm{K}^{+}\right]$. Combining the data from both responding and nonresponding cells showed that, on average, $\left[\mathrm{Ca}^{2+}\right]_{\mathrm{o}}$ elevation produced a relatively small increase in nerve terminal $\left[\mathrm{Ca}^{2+}\right]_{\mathrm{i}}$. 
A
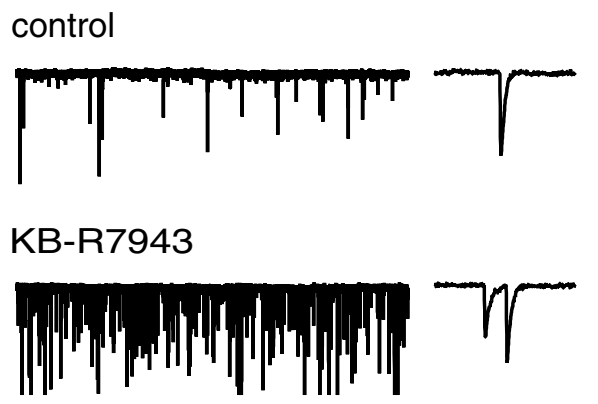

KB-R7943 + $6 \mathrm{mM} \mathrm{Ca}^{2+}$

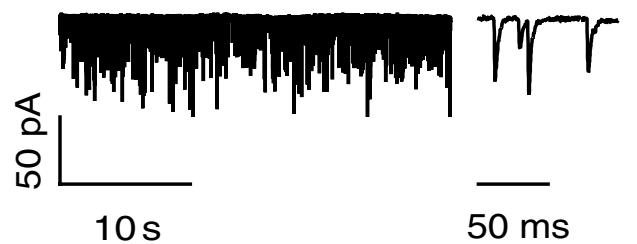

B

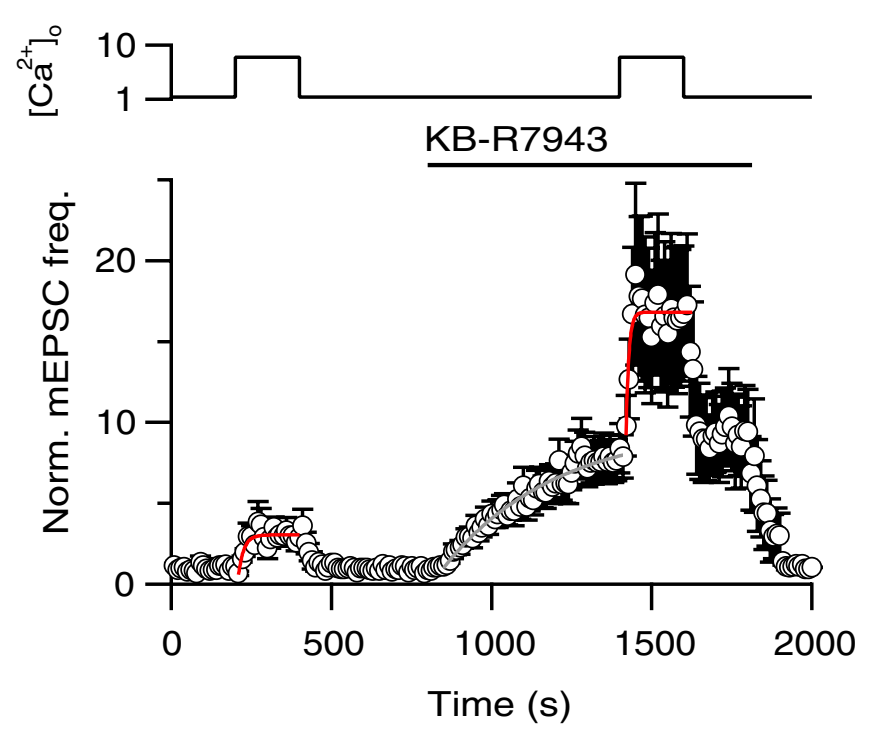

C

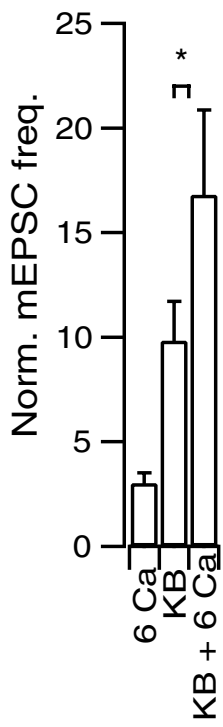

Figure 4. NCX controls baseline spontaneous vesicle fusion but not $\left[\mathrm{Ca}^{2+}\right]_{0}$ dependence. $\boldsymbol{A}$, Representative mEPSCs at baseline (top), after KB-R7943 treatment (middle), and after elevation of

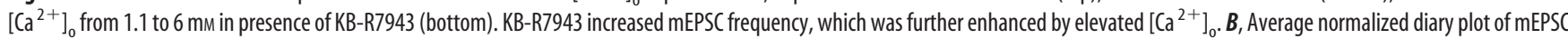
frequency versus time confirms these observations for 5 recordings. Enhancement of $\mathrm{mEPSC}$ frequency by KB-R7943 was fit with a monoexponential function with time constant of $350 \mathrm{~s}$. Rising phases of extracellular $\mathrm{Ca}^{2+}$ enhancement of mEPSC frequency were fit with monoexponential functions with time constants of 17 and $9 \mathrm{~s}$ for before and after KBR7943 application, respectively. C, Summary data for experiment in $\boldsymbol{A}$ and $\boldsymbol{B}$ shows normalized increases in mEPSC frequency compared with baseline for $6 \mathrm{~mm}$ extracellular $\mathrm{Ca}^{2+}$ alone, $\mathrm{KBR7943}$ alone, and $6 \mathrm{~mm} C \mathrm{a}^{2+}$ in the presence of KBR7943.

Enhancement of spontaneous release by extracellular $\mathrm{Ca}^{2+}$ is insensitive to intracellular $\mathrm{Ca}^{2+}$ chelation by BAPTA

We next tested directly whether the enhancement of spontaneous release by extracellular $\mathrm{Ca}^{2+}$ required increases in $\left[\mathrm{Ca}^{2+}\right]_{\mathrm{i}}$ using the $\mathrm{Ca}^{2+}$ chelator BAPTA. Intracellular BAPTA binds $\mathrm{Ca}^{2+}$ with a $K_{\mathrm{d}}$ of $\sim 220 \mathrm{nM}$ and with rapid kinetics (Pethig et al., 1989; Naraghi and Neher, 1997; Bucurenciu et al., 2008), and thereby reduces action potential-evoked exocytosis (Adler et al., 1991; Rozov et al., 2001). The membrane-permeable form of BAPTA, BAPTA-AM, also robustly inhibits action potential-evoked neurotransmitter release (Ouanounou et al., 1999; Abenavoli et al., 2002) after cleavage by endogenous esterases (Ouanounou et al., 1996).

We recorded mEPSCs while $\left[\mathrm{Ca}^{2+}\right]_{\mathrm{o}}$ was increased from 1.1 to $6 \mathrm{~mm}$ both before and after a $10 \mathrm{~min}$ application of BAPTA-AM $(100 \mu \mathrm{M})$. Surprisingly, BAPTA-AM did not decrease baseline spontaneous release or the enhancement by elevation of $\left[\mathrm{Ca}^{2+}\right]_{\mathrm{o}}$ (Fig. $6 \mathrm{~A}, \mathrm{~B}$ ).

We confirmed that BAPTA-AM application altered intracellular $\mathrm{Ca}^{2+}$ buffering under these conditions by testing its action on evoked EPSCs. Extracellular stimulation $(0.1 \mathrm{~Hz})$ elicited a stimulus artifact (upgoing) followed shortly by an EPSC. These EPSCs (superimposed individual EPSCs in gray, average in black) were reversibly blocked by CNQX (Fig. 6C, left, average in blue) confirming that they were mediated by AMPA/kainate receptors. Synaptic transmission recovered after wash (Fig. 6C, right, average in black) and was abolished after perfusion with BAPTA-AM for $400 \mathrm{~s}$ (Fig. 6C, right, average in red). Overall $400 \mathrm{~s}$ application of BAPTA inhibited stimulus-evoked charge transfer by $93 \%$ (Fig. $6 E$ ) indicating that the $600 \mathrm{~s}$ BAPTA-AM application in the spontaneous release experiments would have substantially increased intracellular $\mathrm{Ca}^{2+}$ buffering. The inhibition of stimulusevoked excitatory synaptic transmission was not reversible over the time course measured here, consistent with low membrane permeability of BAPTA.
We also tested whether BAPTA-AM affected the enhancement of mEPSC frequency by extracellular $\mathrm{Ca}^{2+}$ under other conditions. Bath application of $50 \mu \mathrm{M}$ BAPTA-AM did not impact mEPSC changes when $\left[\mathrm{Ca}^{2+}\right]_{0}$ was raised. Likewise neurons incubated in 50-100 $\mu \mathrm{M}$ BAPTA-AM (for $30 \mathrm{~min}$ at $37^{\circ} \mathrm{C}$ ) retained their sensitivity to increased $\left[\mathrm{Ca}^{2+}\right]_{0}$. Thus, enhancement of spontaneous glutamate release by extracellular $\mathrm{Ca}^{2+}$ was insensitive to chelation of intracellular $\mathrm{Ca}^{2+}$ by BAPTA.

Extracellular $\mathrm{Mg}^{2+}$ stimulates spontaneous vesicle fusion

$\left[\mathrm{Ca}^{2+}\right]_{\mathrm{o}}$ changes directly and indirectly modulate a number of ion channels and thereby impact neuronal excitability (Hablitz et al., 1986; Xiong et al., 1997; Immke and McCleskey, 2001; Smith et al., 2004). Extracellular $\mathrm{Mg}^{2+}$ decreases VACC currents and so inhibits synchronous release (Dodge and Rahamimoff, 1967; Carbone et al., 1997; Ikeda et al., 2008). In contrast to this antagonistic effect, $\mathrm{Mg}^{2+}$ has qualitatively similar actions to $\mathrm{Ca}^{2+}$ at other sites such as CaSR (Brown et al., 1993). To further characterize the mechanism by which extracellular $\mathrm{Ca}^{2+}$ regulates spontaneous vesicle fusion we recorded mEPSCs while varying $\left[\mathrm{Mg}^{2+}\right]_{0}$. Removing extracellular $\mathrm{Ca}^{2+}$ and decreasing extracellular $\mathrm{Mg}^{2+}$ markedly reduced mEPSC frequency (Fig. $7 A$, top and middle traces). Elevating $\left[\mathrm{Mg}^{2+}\right]_{\mathrm{o}}$ to $6 \mathrm{mM}$ increased $\mathrm{mEPSC}$ frequency to approximately baseline levels (bottom trace). The concentration-effect relationship for mEPSC frequency and $\left[\mathrm{Mg}^{2+}\right]_{\mathrm{o}}$ had a slope of 0.40 indicating that extracellular $\mathrm{Mg}^{2+}$, like extracellular $\mathrm{Ca}^{2+}$, stimulates spontaneous fusion with low cooperativity (Fig. 7B). We also tested whether extracellular $\mathrm{Mg}^{2+}$ enhanced spontaneous release at physiological $\left[\mathrm{Ca}^{2+}\right]_{\mathrm{o}}$. Following elevation of $\left[\mathrm{Mg}^{2+}\right]_{\mathrm{o}}$ from 1.1 to $6 \mathrm{mM}$ in $1.1 \mathrm{~mm}$ extracellular $\mathrm{Ca}^{2+}$, mEPSC frequency increased nearly twofold (Fig. 7C).

We confirmed that increasing $\left[\mathrm{Mg}^{2+}\right]_{\mathrm{o}}$ over the relevant range inhibited VACC currents in these neocortical neurons. VACC currents activated by a ramp depolarization were in- 
A

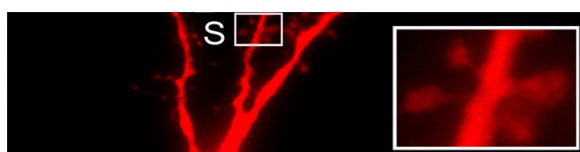

$20 / 5 \mu \mathrm{m}$

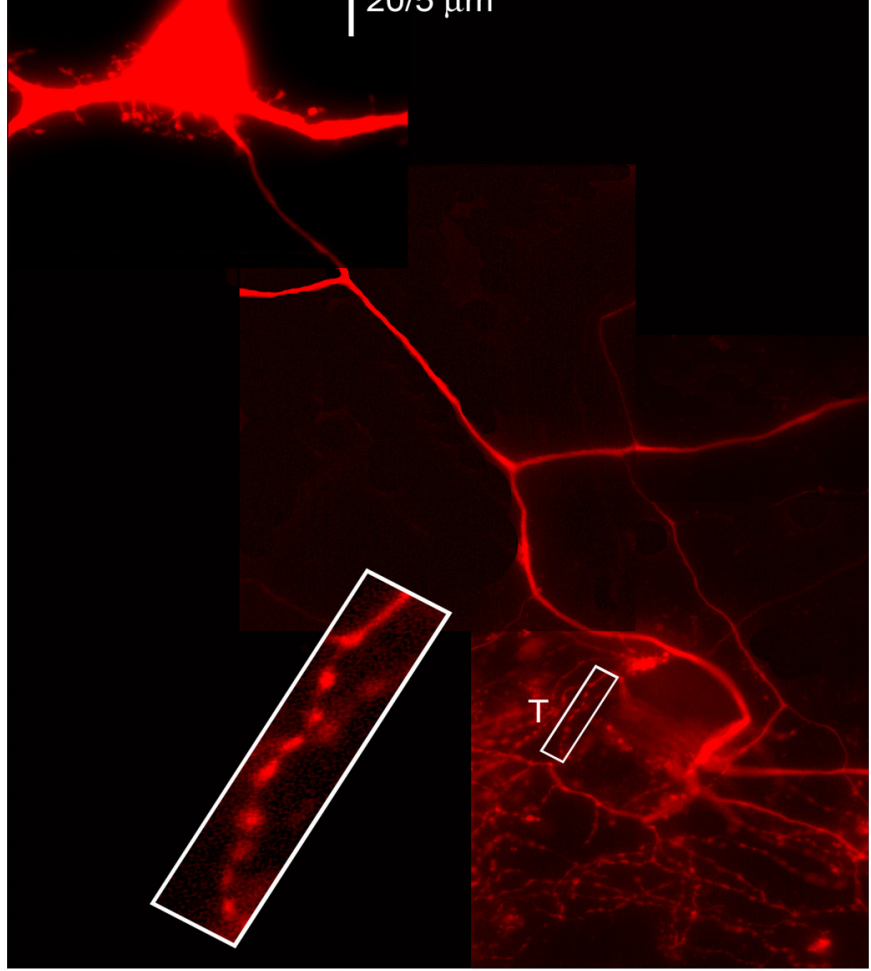

$\mathrm{B}$

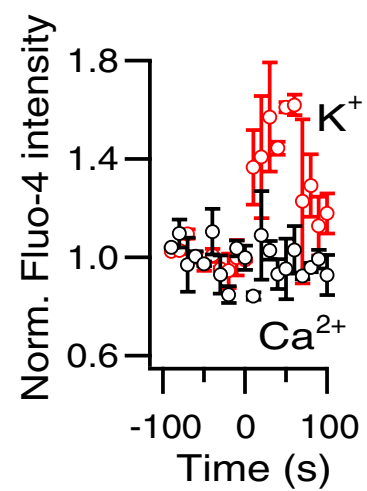

C

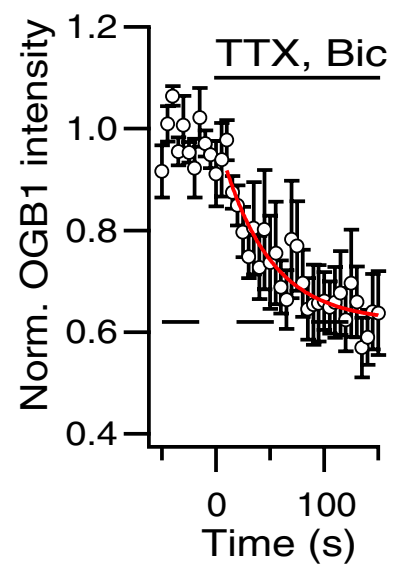

D

\section{Non-responder Responder}

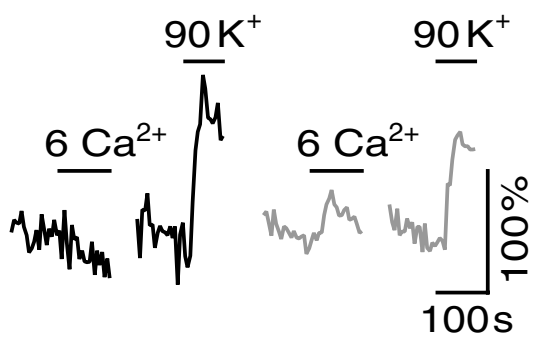

$\mathrm{E}$

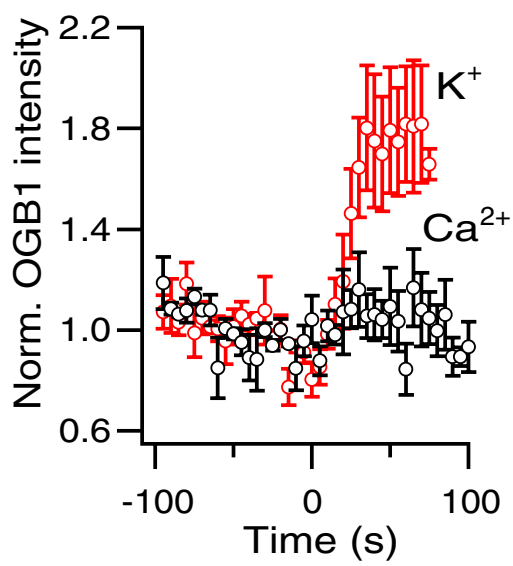

Figure 5. Nerve terminal $\left[\mathrm{Ca}^{2+}\right]_{\mathrm{i}}$ response to change of $\left[\mathrm{Ca}^{2+}\right]_{0}$. $\boldsymbol{A}$, Reconstructed image of pyramidal neuron showing putative punctuate nerve terminals $(\mathrm{T})$ and spines $(\mathrm{S})$. White boxes show presumed axonal and dendritic segments that have been

hibited by extracellular $\mathrm{Mg}^{2+}$ in a concentration-dependent manner (Fig. $7 D)$. Increasing $\left[\mathrm{Mg}^{2+}\right]_{\mathrm{o}}$ shifted the activation of VACC currents in the depolarizing direction and reduced the maximum conductance (Carbone et al., 1997) (Fig. $7 E)$. These data demonstrate that extracellular $\mathrm{Mg}^{2+}$ enhanced spontaneous vesicle fusion, in contrast to its effect on action potential-evoked vesicle fusion (Dodge and Rahamimoff, 1967; Ikeda et al., 2008). This is further evidence that $\mathrm{Ca}^{2+}$ entry via VACC does not mediate spontaneous vesicle fusion.

\section{CaSR activation increases spontaneous} vesicle fusion

CaSR is activated by both increases in $\left[\mathrm{Ca}^{2+}\right]_{\mathrm{o}}$ and $\left[\mathrm{Mg}^{2+}\right]_{\mathrm{o}}$ (Brown et al., 1993) and is expressed in central nerve terminals (Ruat et al., 1995; Chen et al., 2010). CaSR stimulation inhibits the activity of a nonselective cation channel in nerve terminals and impairs synaptic transmission (Smith et al., 2004; Phillips et al., 2008). To test the hypothesis that CaSR activation controls spontaneous vesicle fusion, we first examined the effect of Calindol, an allosteric CaSR agonist (Kessler et al., 2004), on mEPSC frequency. Spontaneous vesicle fusion was increased substantially by Calindol ( $5 \mu$ M, Fig. $8 A$ ). On average, an $800 \mathrm{~s}$ application of Calindol increased mEPSC frequency to $9.7 \pm 3.8$ times that of baseline (Fig. $8 \mathrm{~B}$ ). We also tested the effect of another allosteric CaSR agonist. Cinacalcet $(5 \mu \mathrm{M})$ produced a robust and reversible increase in spontaneous release rate (Fig. 8C). Average mEPSC frequency at the end of a $900 \mathrm{~s}$ application of cinacalcet was $7.9 \pm 3.0$ times that of baseline. These results demonstrate that specific al-

expanded (insets) to illustrate exemplar terminals ( $\mathrm{T}$ ) and spines (S). Scale bar, $20 \mu \mathrm{m}$ (5 $\mu \mathrm{m}$ for insets). B, Average normalized plot of Fluo-4 intensity versus time for responses to extracellular $\mathrm{Ca}^{2+}$ elevation (to $6 \mathrm{~mm}$ ) or $90 \mathrm{~mm}$ extracellu$\operatorname{lar} \mathrm{K}^{+}$in the same boutons ( $n=2$ neurons, average of 35 boutons/neuron). C, Average normalized diary plot of nerve terminal OGB1 intensity decrease in response to tetrodotoxin and bicuculline perfusion ( $n=5$ neurons). The decay was well described by a monoexponential function with time constant of 44 s. D, Average nerve terminal OGB1 fluorescence changes in response to $\mathrm{Ca}^{2+}$ elevation or $90 \mathrm{~mm} \mathrm{~K}^{+}$for two different neurons. Nerve terminals from neuron on left were insensitive to enhancement of $\left[\mathrm{Ca}^{2+}\right]_{0}$ (average signal from 13 putative boutons), while those from neuron on right displayed fluorescence increase (average signal from 35 putative boutons). Both sets of boutons showed robust response to depolarization with $\mathrm{K}^{+}$. $\boldsymbol{E}$, Average normalized bouton $0 \mathrm{~GB} 1$ fluorescence plotted as a function of time for all recordings $(n=5$, 13-53 boutons/recording). 
A

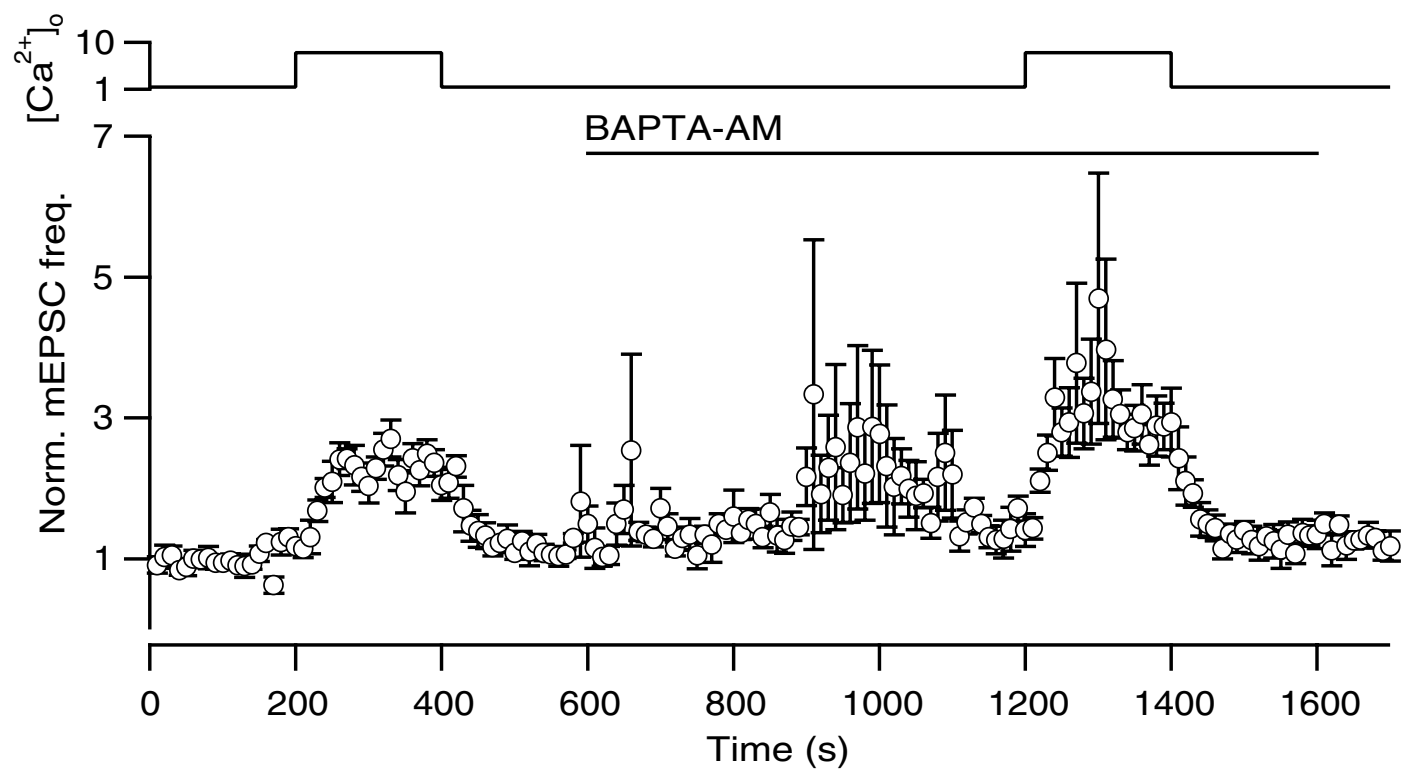

C

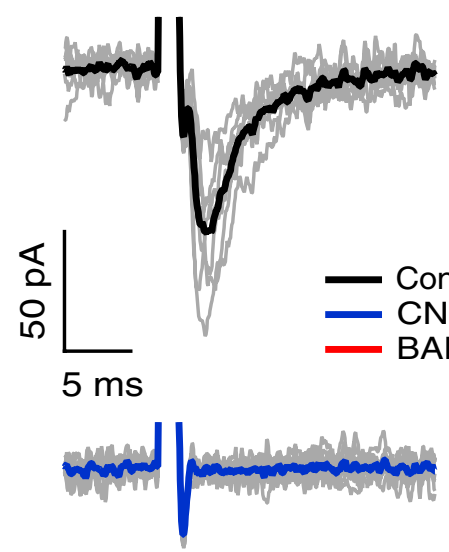

$\mathrm{D}$

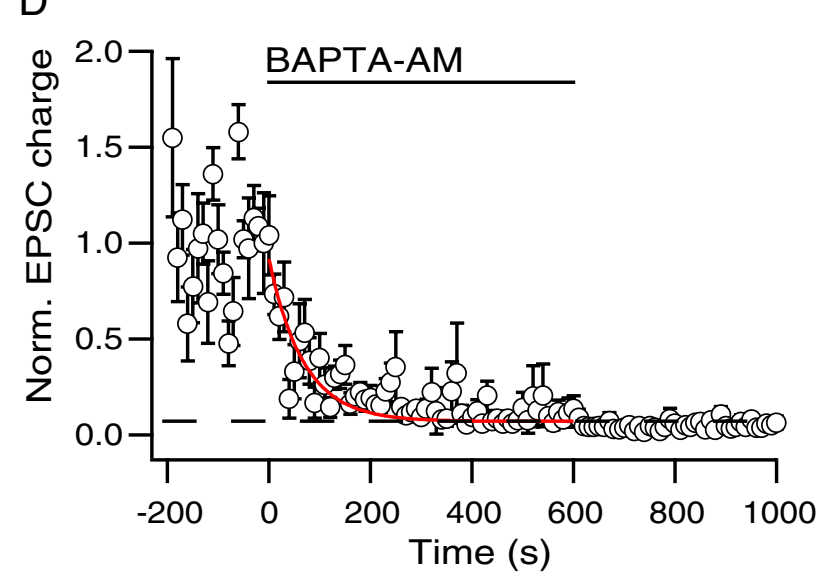

Figure 6. Enhancement of spontaneous release by extracellular $\mathrm{Ca}^{2+}$ is insensitive to intracellular BAPTA. A, Average normalized diary plot of mEPSC frequency versus time showing effect of elevation of $\left[\mathrm{Ca}^{2+}\right]_{0}$ from 1.1 to $6 \mathrm{~mm}$ both before and after $10 \mathrm{~min}$ application of BAPTA-AM $(100 \mu \mathrm{m}, n=6)$. BAPTA did not prevent enhancement of mEPSC frequency by elevation of $\left[\mathrm{Ca}^{2+}\right]_{0}$. $B$, Histogram of normalized steady-state mEPSC frequencies. Average baseline mEPSC frequency was $2.1 \pm 0.54$ events per second and increased to $5.0 \pm 1.5$ at $\left[\mathrm{Ca}^{2+}\right]_{0}=6 \mathrm{mM} . \mathrm{mEPSC}$ frequency in BAPTA-AM and $1.1 \mathrm{~mm}\left[\mathrm{Ca}^{2+}\right]_{0}$ was $3.3 \pm 1.0$ events per second measured during the 100 s before second $\mathrm{Ca}^{2+}$ step. Elevation of $\left[\mathrm{Ca}^{2+}\right]_{0}$ in the presence of intracellular BAPTA increased mEPSC frequency to $7.2 \pm 2.4$ events per second ( $p=0.04$ compared with BAPTA-AM alone). C, Stimulus-evoked EPSCs (left, top, individual traces in gray, average in black) were reduced by CNQX (20 $\mu \mathrm{m}$; average in blue) and BAPTA (right, bottom, average in red) EPSC sfter CNQX was shown in top, right panel. Stimulus artifact truncated for clarity. $\boldsymbol{D}$, Average normalized diary plot of EPSC charge transfer versus time confirms inhibition of evoked synaptic transmission by BAPTA-AM $(n=5)$. Plot fitted with single exponential function with average time constant $(68 \mathrm{~s})$ and base $(0.07)$ from individual recordings. The average EPSC integral was $1.15 \pm 0.46 \mathrm{pC}$ before and $0.080 \pm 0.028 \mathrm{pC}$ after BAPTA-AM and decayed with an average time constant of $67 \pm 20 \mathrm{~s}(n=5)$.

losteric agonists for CaSR stimulated spontaneous glutamate release.

We next tested whether gadolinium $\left(\mathrm{Gd}^{3+}\right)$, a high-affinity CaSR agonist also stimulated spontaneous glutamate release in these neurons (Brown et al., 1993). Gd ${ }^{3+}(20 \mu \mathrm{M})$ produced a large reversible increase in mEPSC frequency (Fig. $8 D$ ). On average, $\mathrm{mEPSC}$ frequency was $31 \pm 11$ times that of baseline after $200 \mathrm{~s}$ application of $\mathrm{Gd}^{3+}$. These results also support our proposal that VACCs are not primary mediators of spontaneous glutamate release, as $\mathrm{Gd}^{3+}$ is a potent inhibitor of VACCmediated $\mathrm{Ca}^{2+}$ influx (Biagi and Enyeart, 1990).

We further examined the role of CaSR signaling in spontaneous vesicle fusion using a CaSR mutant mouse $\left(\mathrm{CaSR}^{-1-}\right)$ (Ho et al., 1995). The CaSR gene in $\mathrm{CaSR}^{-1-}$ mice contains an exon deletion and expresses mutant CaSR with reduced function (Oda et al., 1998). Expression of the CaSR mutant in human embryonic kidney cells confirmed that the exon deletion blocked plasma membrane expression of the receptor (Wang et al., 2009). mEPSCs were recorded from both $\mathrm{CaSR}^{+/+}$and $\mathrm{CaSR}^{-1-}$ neurons (Fig. $8 \mathrm{E}$ ). In $\mathrm{CaSR}^{-1-}$ neurons mEPSC frequency increased as $\left[\mathrm{Ca}^{2+}\right]_{\mathrm{o}}$ was sequentially increased (see also Fig. 1) indicating that CaSR-independent pathways also contribute to the $\left[\mathrm{Ca}^{2+}\right]_{0}$ dependence of mEPSC frequency. The slope of the log-log concentration-effect plot was 0.83 , similar to that observed for the $\mathrm{CaSR}^{+/+}$neurons. However, the concentration-effect curves of mEPSC frequency versus $\left[\mathrm{Ca}^{2+}\right]_{\mathrm{o}}$ for $\mathrm{CaSR}^{+/+}$and $\mathrm{CaSR}^{-1-}$ neurons diverged at lower $\mathrm{Ca}^{2+}$ concentrations (Fig. $8 \mathrm{~F}$ ). We used linear regression of the logarithmically transformed data to test for overall differences between the two datasets. The lines describing $\log$ mEPSC frequency versus $\log \left[\mathrm{Ca}^{2+}\right]_{0}$ had different intercepts for $\mathrm{CaSR}^{+/+}$and $\mathrm{CaSR}^{-/-}$neurons confirming a difference in the $\left[\mathrm{Ca}^{2+}\right]_{\mathrm{o}}$ dependence of mEPSC frequency for the 
A

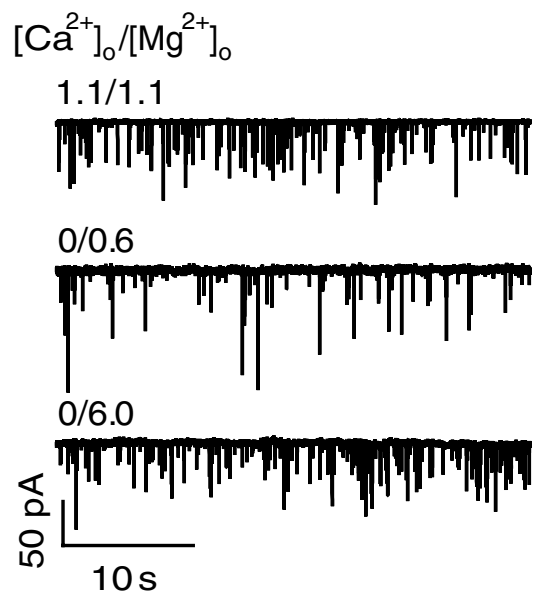

D

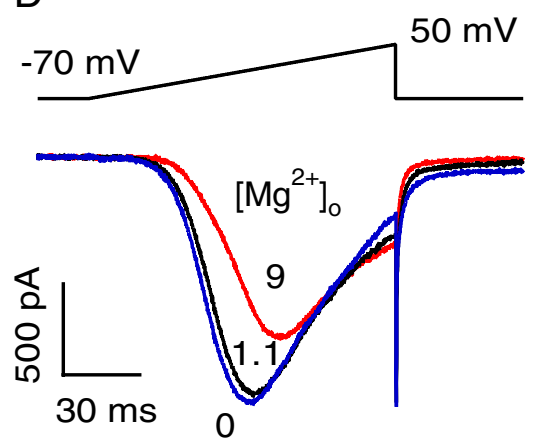

B

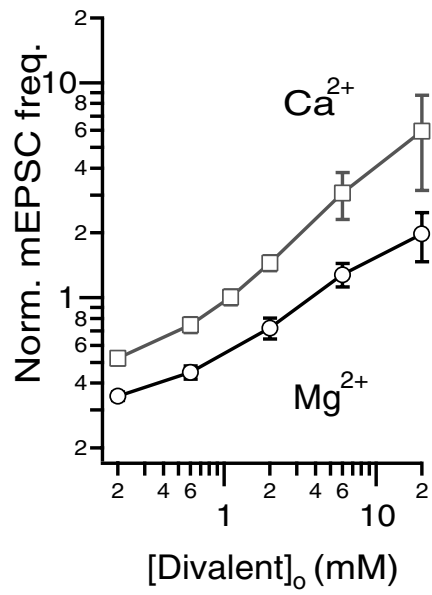

$\mathrm{E}$

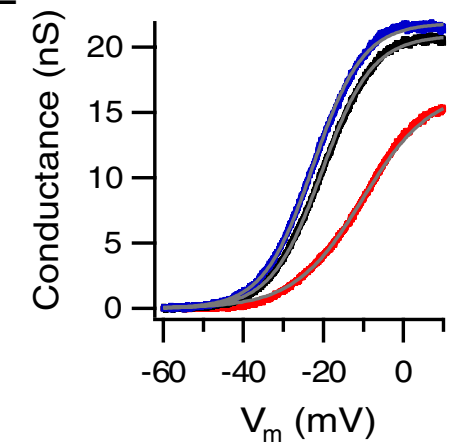

C

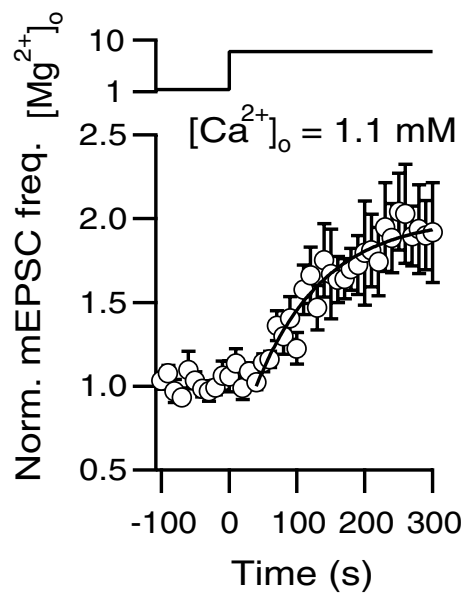

G

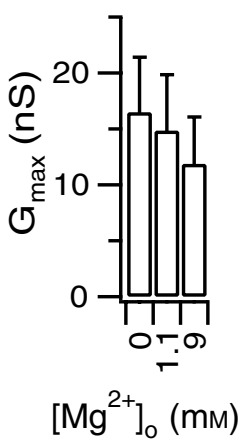

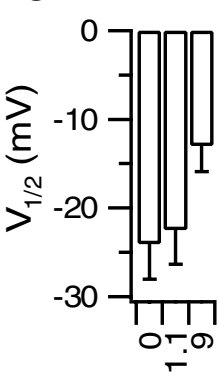

$\left[\mathrm{Mg}^{2+}\right]_{0}(\mathrm{mM})$

Figure 7. Extracellular $\mathrm{Mg}^{2+}$ increases spontaneous glutamate release but inhibits VACC currents. $A$, mEPSCs were recorded in control $\left[\mathrm{Ca}^{2+}\right]_{0}$ and $\left[\mathrm{Mg}^{2+}\right]_{0}(\mathrm{both} 1.1 \mathrm{~mm}$, top). Removal of extracellular $\mathrm{Ca}^{2+}$ and decreasing $\left[\mathrm{Mg}^{2+}\right]_{0}$ markedly reduced mEPSC frequency (middle). Elevation of $\left[\mathrm{Mg}^{2+}\right]_{0}$ in the absence of extracellular $\mathrm{Ca}^{2+}$ increased $\mathrm{mEPSC}$ frequency (bottom). $\boldsymbol{B}$, Concentration- effect curves for mEPSC frequency versus $\left[\mathrm{Mg}^{2+}\right]_{0}$ (circles) and $\left[\mathrm{Ca}^{2+}\right]_{0}$ (squares, replotted from Fig. 1.2). Lines are drawn between points for clarity. All points normalized to mEPSC frequency in control $\left[\mathrm{Ca}^{2+}\right]_{0}$ and $\left[\mathrm{Mg}^{2+}\right]_{0}$ (both $\left.1.1 \mathrm{mM}\right)$. C, Average normalized diary plot of mEPSC frequency versus time demonstrates that elevation of $\left[\mathrm{Mg}^{2+}\right]_{0}$ from 1.1 to $6 \mathrm{~mm}$ increased $\mathrm{mEPSC}$ frequency in the presence of control $\left[\mathrm{Ca}^{2+}\right]_{0}(1.1 \mathrm{~mm} ; n=6)$. Average mEPSC frequency increase was fit with a monoexponential function with time constant of $100 \mathrm{~s}$. D, Representative recording of VACC currents elicited by ramp depolarization ( -70 to $50 \mathrm{mV}$ at $1 \mathrm{mV} / \mathrm{ms}$, top) in zero, 1.1, or $9 \mathrm{~mm}$ extracellular $\mathrm{Mg}^{2+}$. Traces are averages of three consecutive sweeps. Currents remaining in $\mathrm{Cd}^{2+}(100 \mu \mathrm{m})$ were subtracted from the average traces. $\left[\mathrm{Ca}^{2+}\right]_{0}=2 \mathrm{~mm}$ for these recordings. Pipette contained cesium methane-sulfonate solution. $E$, Plots of conductance versus membrane voltage for VACC currents in $\boldsymbol{D}$ (Eq. 1). Extracellular $\mathrm{Mg}^{2+}$ both decreased $G_{\max }$ and shifted $V_{1 / 2}$ to less negative potentials. $F, G$, Histograms show average maximal conductance and $V_{1 / 2}$ as a function of $\left[\mathrm{Mg}^{2+}\right]_{0}$ for three recordings. $G_{\max }$ was 22,21 , and $17 \mathrm{nS}$ and $V_{1 / 2}$ was $-23,-20$, and $-11 \mathrm{mV}$ for $\left[\mathrm{Mg}^{2+}\right]_{0}=0,1.1$, and $9 \mathrm{~mm}$, respectively $(n=3)$.

two genotypes $(p=0.04)$. We have attempted to account for the differences between the two genotypes using a simple model. First, the relationship between mEPSC frequency and $\left[\mathrm{Ca}^{2+}\right]_{\mathrm{o}}$ in $\mathrm{CaSR}^{-1-}$ neurons was fit by least squares to an empirical power function (Eq. 2; Fig. 8 F, blue) (Bucurenciu et al., 2010). We proposed that the $\mathrm{CaSR}^{+/+}$data could be described by the sum of two distinct components: a CaSR-independent relationship identical to that observed in the $\mathrm{CaSR}^{-1-}$ neurons and a CaSRmediated effect. We described this second component with the Hill equation (Fig. $7 F$, red) using the parameters obtained from the affinity for CaSR-modulated currents at murine nerve terminals [0.72 mM (Phillips et al., 2008)], a Hill coefficient of 0.55 taken from the slope of the normalized data (Fig. 2C), and an arbitrary maximum CaSR-dependent mEPSC frequency of 3.2 $\mathrm{s}^{-1}$ (Fig. $8 F$ ). The sum of these two curves described the $\mathrm{CaSR}^{+/+}$data well (Fig. 7F, black). The divergence of the $\mathrm{CaSR}^{+/+}$and $\mathrm{CaSR}^{-1-}$ relationships over the lower range of $\left[\mathrm{Ca}^{2+}\right]_{\mathrm{o}}$ indicates that that the relative contribution of CaSRdependent spontaneous release increases as $\left[\mathrm{Ca}^{2+}\right]_{\mathrm{o}}$ falls. The difference between the two curves suggests that at resting $\left[\mathrm{Ca}^{2+}\right]_{\mathrm{o}}$ (1.1 mm) CaSR activation mediates $\sim 30 \%$ of the spontaneous release. Consistent with this average $\mathrm{mEPSC}$ frequency measured when $\left[\mathrm{Ca}^{2+}\right]_{\mathrm{o}}$ and $\left[\mathrm{Mg}^{2+}\right]_{\mathrm{o}}$ were both $1.1 \mathrm{~mm}$ was $3.2 \pm 0.4 \mathrm{~s}^{-1}$ and $2.3 \pm 0.4 \mathrm{~s}^{-1}$ for $\mathrm{CaSR}^{+/+}$and $\mathrm{CaSR}^{-1-}$ neurons respectively $\left(n=74\right.$ and 23 for $\mathrm{CaSR}^{+/+}$and $\mathrm{CaSR} R^{-1-}$ neurons, respectively). Together, these data indicate that CaSR activation stimulates spontaneous vesicle fusion and the relative contribution made by this pathway is greatest over the range of $\left[\mathrm{Ca}^{2+}\right]_{\mathrm{o}}$ that occurs under physiological and pathological conditions (Nicholson et al., 1978; Jones and Keep, 1988; Nilsson et al., 1996).

\section{Discussion}

Calcium is a pivotal regulator of neuronal communication with numerous synaptic targets. Dissection of the contributions of the component signaling pathways is key to understanding synaptic transmission (Meinrenken et al., 2003; Chicka et al., 2008; Neher and Sakaba, 2008; Smith et al., 2008; Peters et al., 2010). Here we confirm that increasing $\left[\mathrm{Ca}^{2+}\right]_{\mathrm{o}}$ stimulates spontaneous release of glutamate at central neurons (Yamasaki et al., 2006; Xu et al., 2009; Groffen et al., 2010; Yang et al., 2010) but our findings indicate a number of surprising differences between evoked and spontaneous release. First, the $\left[\mathrm{Ca}^{2+}\right]_{0}$ dependence of spontaneous release is very low. Second, spontaneous release is not trig- 
gered by $\mathrm{Ca}^{2+}$ entry via VACC. Third, increases in $\left[\mathrm{Ca}^{2+}\right]_{\mathrm{i}}$ are unnecessary for extracellular $\mathrm{Ca}^{2+}$-mediated spontaneous release. Fourth, extracellular magnesium and allosteric agonists for CaSR increase mEPSC frequency. Finally, CaSR-nullmutant neurons exhibit less spontaneous release. These discoveries indicate that calcium-regulation of spontaneous and evoked release are substantially different, and that presynaptic GPCR activation by extracellular $\mathrm{Ca}^{2+}$ stimulates spontaneous exocytosis.

\section{Calcium modulation of spontaneous release}

The steep relationship between transmitter release and $\left[\mathrm{Ca}^{2+}\right]_{\mathrm{i}}$ has been explained by a model in which five $\mathrm{Ca}^{2+}$ bind cooperatively to synatoptagmin (Geppert et al., 1994; Bollmann et al., 2000; Schneggenburger and Neher, 2000). It was presumed that the same mechanism also regulated spontaneous exocytosis. However, new molecular targets, including Doc2b, have been proposed as the intracellular $\mathrm{Ca}^{2+}$ sensor that regulates spontaneous release (Sun et al., 2007; Groffen et al., 2010). Our data also challenge the idea that $\mathrm{Ca}^{2+}$ regulates spontaneous and evoked release via the same mechanism. We clearly showed that VACC, the route for $\mathrm{Ca}^{2+}$ influx during evoked release, did not transduce the extracellular $\mathrm{Ca}^{2+}$-mediated increase in mEPSC frequency (Figs. 3, 7, 8) consistent with other synapses (Abenavoli et al., 2002; Yamasaki et al., 2006). Surprisingly, in most nerve terminals, $\left[\mathrm{Ca}^{2+}\right]_{\mathrm{i}}$ was not increased by increases in $\left[\mathrm{Ca}^{2+}\right]_{\mathrm{o}}$ (Fig. 5) consistent with spontaneous release being independent of $\left[\mathrm{Ca}^{2+}\right]_{\mathrm{i}}$. Despite strongly reducing evoked release, BAPTA-AM did not reduce mEPSC frequency (Fig. 6), supporting our proposal that another mechanism mediated $\left[\mathrm{Ca}^{2+}\right]_{\mathrm{o}}$-induced increases in mEPSC frequency.

An alternative interpretation, not tested by our experiments, is that increases in $\left[\mathrm{Ca}^{2+}\right]_{\mathrm{o}}$ increased $\left[\mathrm{Ca}^{2+}\right]_{\mathrm{i}}$, but that these fluctuations lie far below the BAPTA $K_{\mathrm{d}}$. In other words, the changes may be too small to be chelated by BAPTA but large enough to trigger vesicle fusion. Consequently we estimated the changes in $\left[\mathrm{Ca}^{2+}\right]_{\mathrm{i}}$ that would be required to produce the measured increase in MEPSC frequency (Fig. 9) using a model of $\left[\mathrm{Ca}^{2+}\right]_{i}$ versus release rate that assumes vesicles undergoing spontaneous and evoked release are mechanistically indistinguishable (Lou et al., 2005). At a resting $\left[\mathrm{Ca}^{2+}\right]_{\mathrm{i}}$ of $100 \mathrm{nM}$, the model predicts $\left[\mathrm{Ca}^{2+}\right]_{\mathrm{i}}$ would have to increase to $252 \mathrm{~nm}$ to pro-
A

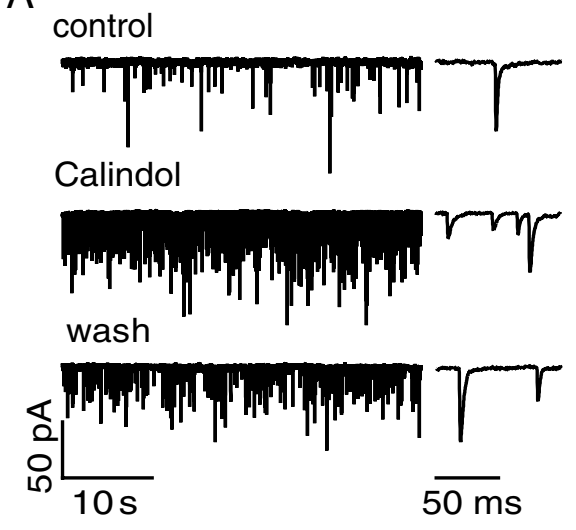

$\mathrm{B}$

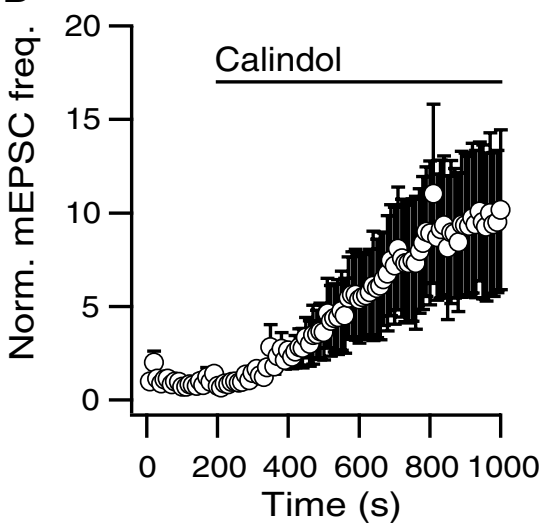

C
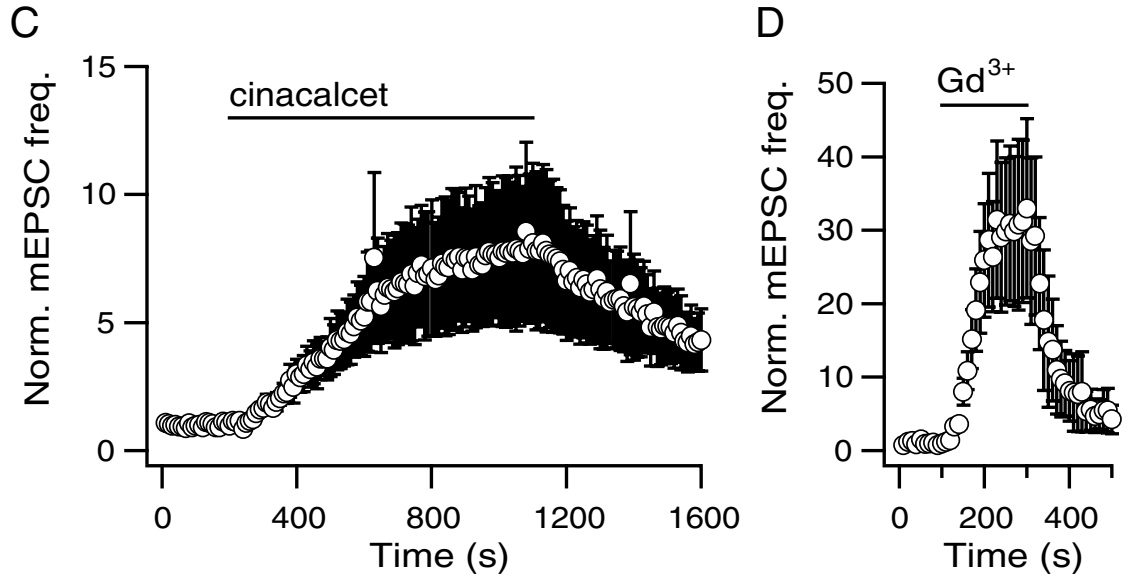

E

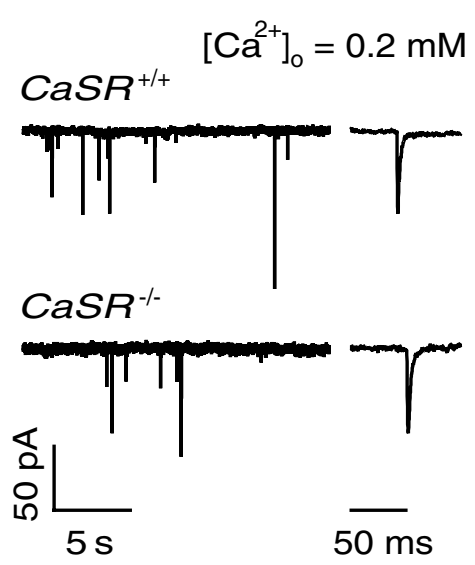

$\mathrm{F}$

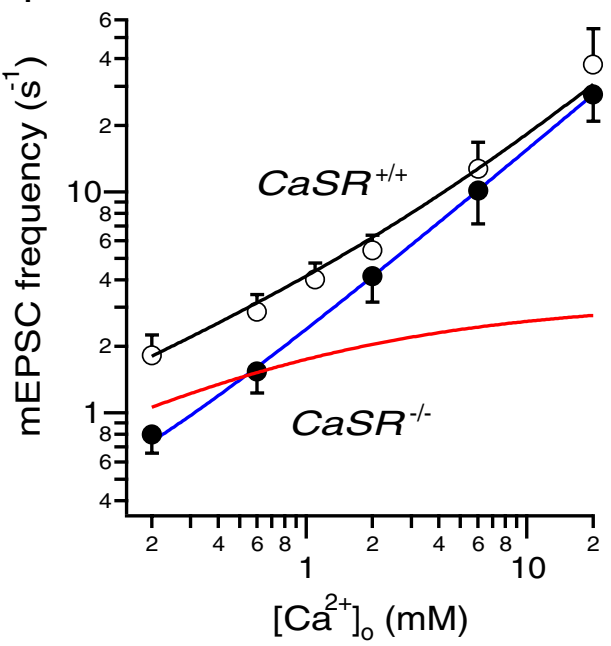

Figure 8. CaSR activation enhances spontaneous glutamate release. $A$, mEPSCs were recorded before (top), after 10 min of Calindol application ( $5 \mu \mathrm{m}$; middle), and after 15 min of wash (bottom). Calindol produced a marked increase in mEPSC frequency. $\boldsymbol{B}$, Average normalized diary plot of mEPSC frequency versus time confirms that Calindol increased spontaneous glutamate release $(n=6)$. $\boldsymbol{C}, \boldsymbol{D}$, Average normalized diary plots show that cinacalcet $(5 \mu \mathrm{m}, n=4)$ and $\mathrm{Gd}^{3+}(20 \mu \mathrm{m}$, $n=4$ ) reversibly enhance spontaneous release rate. $E$, Traces show mEPSCs recorded from CaSR ${ }^{+/+}$(top) and CaSR $R^{-1-}$ neurons (bottom) in low $\left[\mathrm{Ca}^{2+}\right]_{0}(0.2 \mathrm{mM}) .\left[\mathrm{Mg}^{2+}\right]_{0}=0.5 \mathrm{~mm}$ for these experiments. $F$, Non-normalized concentrationeffect curves of mEPSC frequency versus $\left[\mathrm{Ca}^{2+}\right]_{0}$ for $\mathrm{CaSR}^{+/+}$(open circles) and $\mathrm{CaSR}^{-1-}$ (closed circles) neurons. mEPSC frequency was reduced in CaSR ${ }^{-1-}$ neurons over the low range of $\left[\mathrm{Ca}^{2+}\right]_{0}$. $\mathrm{CaSR}^{-1-}$ data were fit with a power function (Eq. 2, blue; $y_{0}=0.16, A=2.23 \mathrm{~s}^{-1}, z=0.84$ ) and $\operatorname{CaSR}^{+1+}$ data were described by the sum of a power function and Hill equation (sum of Eqs. 2 and 3 , black curve; $A=2.23 \mathrm{~s}^{-1}, z=0.84, y_{\max }=3.2 \mathrm{~s}^{-1}, \mathrm{EC}_{50}=0.72 \mathrm{~mm}$, and $n=0.55$ ). Hill function (Eq. 3) is shown in red. 


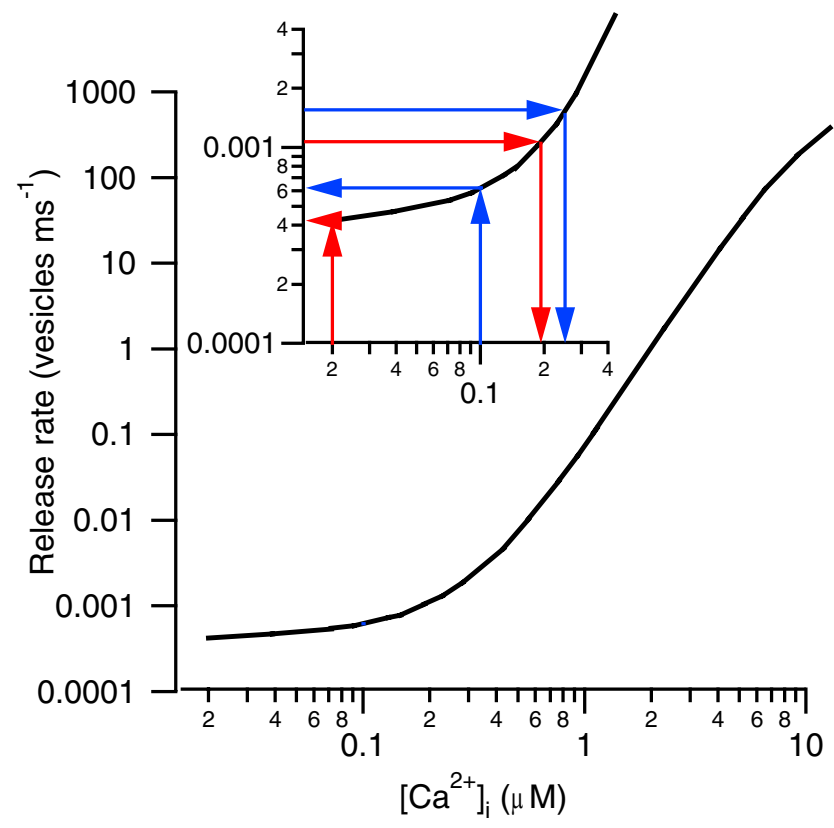

Figure 9. $\left[\mathrm{Ca}^{2+}\right]_{\mathrm{i}}$ elevations should be affected by BAPTA. We used the relationship between $\left[\mathrm{Ca}^{2+}\right]_{i}$ and vesicle fusion rates described by a model comprised of five allosterically linked $\mathrm{Ca}^{2+}$ binding sites and a $\mathrm{Ca}^{2+}$ independent route (Lou et al., 2005), to address the possibility that extracellular $\mathrm{Ca}^{2+}$ enhanced spontaneous release rate by increasing $\left[\mathrm{Ca}^{2+}\right]_{\mathrm{i}}$ in the presence of BAPTA-AM (Fig. 6). The black curve was drawn according to the work of Lou et al. (2005). Blue and red arrows indicate the changes in $\left[\mathrm{Ca}^{2+}\right]_{i}$ necessary to account for the measured 2.5-fold increase in mEPSC frequency upon elevation of $\left[\mathrm{Ca}^{2+}\right]_{0}$ from 1.1 to $6 \mathrm{~mm}$ (Fig. 6) for basal $\left[\mathrm{Ca}^{2+}\right]_{\mathrm{i}}$ of 100 or $20 \mathrm{~nm}$, respectively (inset). $\left[\mathrm{Ca}^{2+}\right]_{i}$ would have had to increase to 252 or $193 \mathrm{~nm}$, respectively, which should have been sensitive to chelation by BAPTA-AM.

duce the 2.5-fold enhancement of mEPSC frequency (Fig. 6) measured when $\left[\mathrm{Ca}^{2+}\right]_{0}$ was increased from 1.1 to $6 \mathrm{~mm}$ (Fig. 9, inset, blue arrows). This value is above the $K_{\mathrm{d}}$ for $\mathrm{Ca}^{2+}$ binding to BAPTA ( 220 nM) (Naraghi and Neher, 1997; Bucurenciu et al., 2008 ) indicating that BAPTA should influence any $\left[\mathrm{Ca}^{2+}\right]_{\mathrm{i}}$ rise. Even assuming a lower basal $\left[\mathrm{Ca}^{2+}\right]_{\mathrm{i}}(20 \mathrm{nM})$ the model predicts that BAPTA would impact the $\left[\mathrm{Ca}^{2+}\right]_{i}$ rise (193 nM; Fig. 9, inset, red arrows). Together these findings indicate it is highly unlikely that spontaneous release was enhanced due to elevations of $\left[\mathrm{Ca}^{2+}\right]_{\mathrm{i}}$.

How do our data sit with other reports? An allosteric model consisting of a pathway independent of $\left[\mathrm{Ca}^{2+}\right]_{\mathrm{i}}$ for vesicle fusion and five binding sites for $\mathrm{Ca}^{2+}$, is a better fit to the relationship between $\left[\mathrm{Ca}^{2+}\right]_{\mathrm{i}}$ and transmitter release than simpler cooperativity models (Lou et al., 2005). The lack of effect of BAPTA-AM on spontaneous release in our experiments is consistent with such a $\left[\mathrm{Ca}^{2+}\right]_{\mathrm{i}}$-independent pathway. Inclusion of CaSR in this model would place it upstream of the $\left[\mathrm{Ca}^{2+}\right]_{\mathrm{i}}$-independent step and lead to the prediction that CaSR regulates the "willingness" or rate of $\left[\mathrm{Ca}^{2+}\right]_{\mathrm{i}}$-independent vesicle fusion.

The limiting slope (0.63) for the concentration-effect relationship in $\mathrm{CaSR}^{+/+}$neurons (Fig. 1) was close to the 0.66 measured at the foot of the $\mathrm{Ca}^{2+}$ range at the calyx of Held (Lou et al., 2005). A similar, low dependence of mEPSC frequency on $\left[\mathrm{Ca}^{2+}\right]_{\mathrm{o}}$ was reported at the neuromuscular junction (Hubbard, 1961) and in central neurons (Groffen et al., 2010; but see Xu et al., 2009). Variation in the relationship between $\left[\mathrm{Ca}^{2+}\right]_{\mathrm{o}}$ and mEPSC frequency combined with sensitivity to release from calcium stores (Llano et al., 2000) and the clear $\left[\mathrm{Ca}^{2+}\right]_{\mathrm{i}}$ dependence of multiquantal release ( $\mathrm{Li}$ et al., 2009) indicate that the action of
$\mathrm{Ca}^{2+}$ may depend on the synapse under study. Spontaneous and evoked synaptic transmissions operate via distinct vesicle pools (Sara et al., 2005; Fredj and Burrone, 2009) and $\left[\mathrm{Ca}^{2+}\right]_{\mathrm{i}}$ sensors (Sun et al., 2007; Groffen et al., 2010). Consequently the reported variation in the $\left[\mathrm{Ca}^{2+}\right]_{0}$ dependence of spontaneous release could reflect differences between neurons in the relative abundance of vesicle pools or $\left[\mathrm{Ca}^{2+}\right]_{\mathrm{i}}$ sensors.

\section{CaSR signaling and vesicle fusion}

In parathyroid cells, CaSR activates phospholipase C (PLC) through the $\mathrm{G}_{\mathrm{q}}$ family of $\mathrm{G}$-proteins (Brown and MacLeod, 2001) which increases inositol triphosphate $\left(\mathrm{IP}_{3}\right)$ and diacylglycerol (DAG) (Wang et al., 2003; Awumey et al., 2007). If CaSR also couples to PLC in nerve terminals, there are at least three possible mechanisms by which CaSR may promote vesicle fusion. CaSR activation could increase $\mathrm{IP}_{3}$ and promote $\mathrm{Ca}^{2+}$ release from intracellular stores (Khodakhah and Ogden, 1993), elevating $\left[\mathrm{Ca}^{2+}\right]_{\mathrm{i}}$ and promoting exocytosis. $\mathrm{Ca}^{2+}$ release from intracellular stores has been shown to promote spontaneous neurotransmitter release in neurons (Emptage et al., 2001; Sharma and Vijayaraghavan, 2003; Vyleta and Smith, 2008). However, our demonstration that BAPTA does not decrease the enhancement of spontaneous release by extracellular $\mathrm{Ca}^{2+}$ argues against a primary role for calcium release from stores. A second mechanism is that CaSR may promote exocytosis by increasing DAG levels in the nerve terminal plasma membrane. DAG analogues potentiate both spontaneous and AP-evoked neurotransmitter release, via presynaptic protein kinase $\mathrm{C}$ and the munc13 family of vesicle priming proteins (Weirda et al., 2007; Lou et al., 2008). Phorbol esters increased vesicle fusion at basal $\left[\mathrm{Ca}^{2+}\right]_{\mathrm{i}}$ (Lou et al., 2005), providing a mechanism for increased spontaneous release independent of increases in $\left[\mathrm{Ca}^{2+}\right]_{\mathrm{i}}$. Third, PLC-catalyzed reduction of phosphatidylinositol 4,5-bisphosphate $\left(\mathrm{PIP}_{2}\right)$ levels could change vesicle fusion. $\mathrm{PIP}_{2}$ hydrolysis is necessary for vesicle scission from the plasma membrane (Liu et al., 2009). Because successful endocytosis is necessary for exocytosis (Hosoi et al., 2009), activation of $\mathrm{PIP}_{2}$ hydrolysis may maintain release sites or vesicle pools. $\mathrm{PIP}_{2}$ could also work by localizing synaptotagmin to presynaptic release sites (Bai et al., 2004) or enhancing Doc2b-mediated fusion (Groffen et al., 2010).

\section{Consequences of presynaptic CaSR signaling in central neurons}

CaSR activation blocks nonselective cation channel (NSCC) currents in nerve terminals (Smith et al., 2004; Chen et al., 2010). NSCC currents were proposed to broaden the presynaptic action potential, prolong calcium entry and potentiate synaptic transmission (Smith et al., 2004). Moreover, evoked release was decreased by CaSR agonists and enhanced in $\mathrm{CaSR}^{-/-}$neuronal pairs (Phillips et al., 2008). The CaSR-NSCC signaling pathway was proposed to attenuate the impact of decreases in brain $\left[\mathrm{Ca}^{2+}\right]_{\mathrm{o}}$ (Nicholson et al., 1978; Nilsson et al., 1996) which are expected to substantially reduce release probability (Rusakov and Fine, 2003). However, the change in mEPSC frequency (Fig. 2 B) is more than an order of magnitude slower than the change in NSCC currents following alteration of $\left[\mathrm{Ca}^{2+}\right]_{0}$, indicating that changes in spontaneous release will only occur after sustained decreases in $\left[\mathrm{Ca}^{2+}\right]_{\mathrm{o}}$ such as those observed during prolonged neuronal activity or pathological stimuli (Nilsson et al., 1996). Moreover, CaSR activation increases spontaneous release in contrast to its inhibitory effect on evoked release.

The CaSR-mEPSC pathway may serve additional roles if CaSR is modulated by other agonists in addition to $\mathrm{Ca}^{2+}$ and $\mathrm{Mg}^{2+}$. 
Spermine and spermidine are released by brain tissue and may function as neuromodulators via CaSR (Masuko et al., 2003; Chen et al., 2007). As well as decreasing evoked release (Phillips et al., 2008) our data predict that polyamines will increase spontaneous release of glutamate. This could be important to sustain or grow new synaptic connections (McKinney et al., 1999; Vizard et al., 2008).

\section{Other modulators of mEPSC frequency}

Only $\sim 30 \%$ of the basal mEPSCs resulted from CaSR activation, however our model predicts that this will increase during periods of decreased $\left[\mathrm{Ca}^{2+}\right]_{\mathrm{o}}$. Since block of NCX increased mEPSC frequency this suggests that under basal conditions NCX has an important role countering increases in $\left[\mathrm{Ca}^{2+}\right]_{\mathrm{i}}$. It remains unclear how CaSR-independent spontaneous release is activated (Fig. $8 F$ ). In addition to release from intracellular stores (Friel and Chiel, 2008), activation of other extracellular $\mathrm{Ca}^{2+}$-sensitive GPCRs is possible. These receptors include the extracellular $\mathrm{Ca}^{2+}$-sensor, GPRC6A (Wellendorph and Bräuner-Osborne, 2004), which has a lower affinity than CaSR, and members of the metabotropic glutamate receptor family (Tabata and Kano, 2004).

In conclusion, we have shown that the extracellular $\mathrm{Ca}^{2+} \mathrm{de}-$ pendence of spontaneous glutamate release in neocortical neurons is of low-order, does not require increases in $\left[\mathrm{Ca}^{2+}\right]_{\mathrm{i}}$, and involves activation of CaSR. Calcium regulates action potentialevoked and spontaneous neurotransmitter release differently, and synaptic cleft $\mathrm{Ca}^{2+}$ promotes spontaneous vesicle fusion by activation of a presynaptic GPCR.

\section{References}

Abenavoli A, Forti L, Bossi M, Bergamaschi A, Villa A, Malgaroli A (2002) Multimodal quantal release at individual hippocampal synapses: evidence for no lateral inhibition. J Neurosci 22:6336-6346.

Adler EM, Augustine GJ, Duffy SN, Charlton MP (1991) Alien intracellular calcium chelators attenuate neurotransmitter release at the squid giant synapse. J Neurosci 11:1496-1507.

Atasoy D, Ertunc M, Moulder KL, Blackwell J, Chung C, Su J, Kavalali ET (2008) Spontaneous and evoked glutamate release activates two populations of NMDA receptors with limited overlap. J Neurosci 28:10151-10166.

Augustine GJ, Charlton MP (1986) Calcium dependence of presynaptic calcium current and post-synaptic response at the squid giant synapse. J Physiol 381:619-640.

Augustine GJ, Adler EM, Charlton MP (1991) The calcium signal for transmitter secretion from presynaptic nerve terminals. Ann N Y Acad Sci 635:365-381.

Awumey EM, Howlett AC, Putney JW Jr, Diz DI, Bukoski RD (2007) $\mathrm{Ca}^{2+}$ mobilization through dorsal root ganglion $\mathrm{Ca}^{2+}$ sensing receptor stably expressed in HEK293 cells. Am J Physiol Cell Physiol 292:C1895-C1905.

Bai J, Tucker WC, Chapman ER (2004) PIP2 increases the speed of response of synaptotagmin and steers its membrane-penetration activity toward the plasma membrane. Nat Struct Mol Biol 11:36-44.

Biagi BA, Enyeart JJ (1990) Gadolinium blocks low- and high-threshold calcium currents in pituitary cells. Am J Physiol Cell Physiol 259:C515-C520.

Bollmann JH, Sakmann B, Borst JG (2000) Calcium sensitivity of glutamate release in a calyx-type terminal. Science 289:953-957.

Borst JG, Sakmann B (1996) Calcium influx and transmitter release in a fast CNS synapse. Nature 383:431-434.

Brown EM, MacLeod RJ (2001) Extracellular calcium sensing and extracellular calcium signaling. Physiol Rev 81:239-297.

Brown EM, Gamba G, Riccardi D, Lombardi M, Butters R, Kifor O, Sun A, Hediger MA, Lytton J, Hebert SC (1993) Cloning and characterization of an extracellular $\mathrm{Ca}(2+)$-sensing receptor from bovine parathyroid. Nature 366:575-580.

Bucurenciu I, Kulik A, Schwaller B, Frotscher M, Jonas P (2008) Nanodomain coupling between $\mathrm{Ca}^{2+}$ channels and $\mathrm{Ca}^{2+}$ sensors promotes fast and efficient transmitter release at a cortical GABAergic synapse. Neuron 57:536-545.

Bucurenciu I, Bischofberger J, Jonas P (2010) A small number of open $\mathrm{Ca}^{2+}$ channels trigger transmitter release at a central GABAergic synapse. Nat Neurosci 13:19-21.

Carbone E, Lux HD, Carabelli V, Aicardi G, Zucker H (1997) $\mathrm{Ca}^{2+}$ and $\mathrm{Na}+$ permeability of high-threshold $\mathrm{Ca}^{2+}$ channels and their voltagedependent block by $\mathrm{Mg}^{2+}$ ions in chick sensory neurons. J Physiol 504:1-15.

Chen W, Harnett MT, Smith SM (2007) Modulation of neuronal voltageactivated calcium and sodium channels by polyamines and $\mathrm{pH}$. Channels 1:281-290.

Chen W, Bergsman JB, Wang X, Gilkey G, Pierpoint CR, Daniel EA, Awumey EM, Dauban P, Dodd RH, Ruat M, Smith SM (2010) Presynaptic external calcium signaling involves the calcium-sensing receptor in neocortical nerve terminals. PLoS One 5:e8563.

Chicka MC, Hui E, Liu H, Chapman ER (2008) Synaptotagmin arrests the SNARE complex before triggering fast, efficient membrane fusion in response to $\mathrm{Ca}^{2+}$. Nat Struct Mol Biol 15:827-835.

Chung C, Barylko B, Leitz J, Liu X, Kavalali ET (2010) Acute dynamin inhibition dissects synaptic vesicle recycling pathways that drive spontaneous and evoked neurotransmission. J Neurosci 30:1363-1376.

Del Castillo J, Katz B (1954) Quantal components of the end-plate potential. J Physiol 124:560-573.

Dodge FA Jr, Rahamimoff R (1967) Co-operative action of calcium ions in transmitter release at the neuromuscular junction. J Physiol 193:419-432.

Elmqvist D, Feldman DS (1965a) Spontaneous activity at a mammalian neuromuscular junction in tetrodotoxin. Acta Physiol Scand 64:475-476.

Elmqvist D, Feldman DS (1965b) Calcium dependence of spontaneous acetylcholine release at mammalian motor nerve terminals. J Physiol 181:487-497.

Emptage NJ, Reid CA, Fine A (2001) Calcium stores in hippocampal synaptic boutons mediate short-term plasticity, store-operated $\mathrm{Ca}^{2+}$ entry, and spontaneous transmitter release. Neuron 29:197-208.

Fatt P, Katz B (1950) Some observations on biological noise. Nature 166:597-598.

Fontana G, Rogowski RS, Blaustein MP (1995) Kinetic properties of the sodium-calcium exchanger in rat brain synaptosomes. J Physiol 485:349-364.

Fredj NB, Burrone J (2009) A resting pool of vesicles is responsible for spontaneous vesicle fusion at the synapse. Nat Neurosci 12:751-758.

Friel DD, Chiel HJ (2008) Calcium dynamics: analyzing the $\mathrm{Ca}^{2+}$ regulatory network in intact cells. Trends Neurosci 31:8-19.

Geppert M, Goda Y, Hammer RE, Li C, Rosahl TW, Stevens CF, Südhof TC (1994) Synaptotagmin I: a major $\mathrm{Ca}^{2+}$ sensor for transmitter release at a central synapse. Cell 79:717-727.

Groffen AJ, Martens S, Díez Arazola R, Cornelisse LN, Lozovaya N, de Jong AP, Goriounova NA, Habets RL, Takai Y, Borst JG, Brose N, McMahon $\mathrm{HT}$, Verhage $\mathrm{M}$ (2010) Doc2b is a high-affinity $\mathrm{Ca}^{2+}$ sensor for spontaneous neurotransmitter release. Science 327:1614-1618.

Hablitz JJ, Heinemann U, Lux HD (1986) Step reductions in extracellular $\mathrm{Ca}^{2+}$ activate a transient inward current in chick dorsal root ganglion cells. Biophys J 50:753-757.

Hille B (2001) Ion channels of excitable membranes. Sunderland, MA: Sinauer.

Hillyard DR, Monje VD, Mintz IM, Bean BP, Nadasdi L, Ramachandran J, Miljanich G, Azimi-Zoonooz A, McIntosh JM, Cruz LJ, Imperial JS, Olivera BM (1992) A new conus peptide ligand for mammalian presynaptic $\mathrm{Ca}^{2+}$ channels. Neuron 9:69-77.

Ho C, Conner DA, Pollak MR, Ladd DJ, Kifor O, Warren HB, Brown EM, Seidman JG, Seidman CE (1995) A mouse model of human familial hypocalciuric hypercalcemia and neonatal severe hyperparathyroidism. Nat Genet 11:389-394.

Hosoi N, Holt M, Sakaba T (2009) Calcium dependence of exo- and endocytotic coupling at a glutamatergic synapse. Neuron 63:216-229.

Hubbard JI (1961) The effect of calcium and magnesium on the spontaneous release of transmitter from mammalian motor nerve endings. J Physiol 159:507-517.

Ikeda K, Yanagawa Y, Bekkers JM (2008) Distinctive quantal properties of neurotransmission at excitatory and inhibitory autapses revealed using variance-mean analysis. J Neurosci 28:13563-13573. 
Immke DC, McCleskey EW (2001) Lactate enhances the acid-sensing $\mathrm{Na}^{+}$ channel on ischemia-sensing neurons. Nat Neurosci 4:869-870.

Johnson I, Spence MTZ (2010) The Molecular Probes handbook, Ed 11. Carlsbad, CA: Invitrogen.

Jones HC, Keep RF (1988) Brain fluid calcium concentration and response to acute hypercalcaemia during development in the rat. J Physiol 402:579-593.

Jun K, Piedras-Rentería ES, Smith SM, Wheeler DB, Lee SB, Lee TG, Chin H, Adams ME, Scheller RH, Tsien RW, Shin HS (1999) Ablation of P/Qtype $\mathrm{Ca}(2+)$ channel currents, altered synaptic transmission, and progressive ataxia in mice lacking the alpha $(1 \mathrm{~A})$-subunit. Proc Natl Acad Sci U S A 96:15245-15250.

Katz B, Miledi R (1965) The effect of calcium on acetylcholine release from motor nerve terminals. Proc R Soc Lond B Biol Sci 161:496-503.

Kessler A, Faure H, Petrel C, Ruat M, Dauban P, Dodd RH (2004) N(2)benzyl-N-(1)-(1-(1-naphthyl)ethyl)-3-phenylpropane-1,2-diamines and conformationally restrained indole analogues: development of Calindol as a new calcimimetic acting at the calcium sensing receptor. Bioorg Med Chem Lett 14:3345-3349.

Khodakhah K, Ogden D (1993) Functional heterogeneity of calcium release by inositol triphosphate in single Purkinje neurones, cultured cerebellar astrocytes, and peripheral tissues. Proc Natl Acad Sci U S A 90:4976-4980

Kimura J, Watano T, Kawahara M, Sakai E, Yatabe J (1999) Directionindependent block of bi-directional $\mathrm{Na}^{+} / \mathrm{Ca}^{2+}$ exchange current by KBR7943 in guinea-pig cardiac myocytes. Br J Pharmacol 128:969-974.

Li GL, Keen E, Andor-Ardó D, Hudspeth AJ, von Gersdorff H (2009) The unitary event underlying multiquantal EPSCs at a hair cell's ribbon synapse. J Neurosci 29:7558-7568.

Liu J, Sun Y, Drubin DG, Oster GF (2009) The mechanochemistry of endocytosis. PloS Biol 7:e1000204.

Llano I, González J, Caputo C, Lai FA, Blayney LM, Tan YP, Marty A (2000) Presynaptic calcium stores underlie large-amplitude miniature IPSCs and spontaneous calcium transients. Nat Neurosci 3:1256-1265.

Llinás R, Steinberg IZ, Walton K (1976) Presynaptic calcium currents and their relation to synaptic transmission: voltage clamp study in squid giant synapse and theoretical model for the calcium gate. Proc Natl Acad Sci U S A 73:2918-2922.

Lou X, Scheuss V, Schneggenburger R (2005) Allosteric modulation of the presynaptic $\mathrm{Ca}^{2+}$ sensor for vesicle fusion. Nature 435:497-501.

Lou X, Korogod N, Brose N, Schneggenburger R (2008) Phorbol esters modulate spontaneous and $\mathrm{Ca}^{2+}$-evoked transmitter release via acting on both Munc13 and protein kinase C. J Neurosci 28:8257-8267.

Masuko T, Kusama-Eguchi K, Sakata K, Kusama T, Chaki S, Okuyama S, Williams K, Kashiwagi K, Igarashi K (2003) Polyamine transport, accumulation, and release in brain. J Neurochem 84:610-617.

McKinney RA, Capogna M, Dürr R, Gähwiler BH, Thompson SM (1999) Miniature synaptic events maintain dendritic spines via AMPA receptor activation. Nat Neurosci 2:44-49.

Meinrenken CJ, Borst JG, Sakmann B (2003) Local routes revisited: the space and time dependence of the $\mathrm{Ca}^{2+}$ signal for phasic transmitter release at the rat calyx of Held. J Physiol 547:665-689.

Momiyama A, Takahashi T (1994) Calcium channels responsible for potassium-induced transmitter release at rat cerebellar synapses. J Physiol 476:197-202.

Nachshen DA, Sanchez-Armass S, Weinstein AM (1986) The regulation of cytosolic calcium in rat brain synaptosomes by sodium-dependent calcium efflux. J Physiol 381:17-28.

Naraghi M, Neher E (1997) Linearized buffered $\mathrm{Ca}^{2+}$ diffusion in microdomains and its implications for calculation of $\left[\mathrm{Ca}^{2+}\right]$ at the mouth of a calcium channel. J Neurosci 17:6961-6973.

Neher E, Sakaba T (2008) Multiple roles of calcium ions in the regulation of neurotransmitter release. Neuron 59:861-872.

Nicholson C, ten Bruggencate G, Stöckle H, Steinberg R (1978) Calcium and potassium changes in extracellular microenvironment of cat cerebellar cortex. J Neurophysiol 41:1026-1039.

Nilsson P, Laursen H, Hillered L, Hansen AJ (1996) Calcium movements in traumatic brain injury: the role of glutamate receptor-operated ion channels. J Cereb Blood Flow Metab 16:262-270.

Oda Y, Tu CL, Pillai S, Bikle DD (1998) The calcium sensing receptor and its alternatively spliced form in keratinocyte differentiation. J Biol Chem 273:23344-23352.
Ouanounou A, Zhang L, Tymianski M, Charlton MP, Wallace MC, Carlen PL (1996) Accumulation and extrusion of permeant $\mathrm{Ca}^{2+}$ chelators in attenuation of synaptic transmission at hippocampal CAl neurons. Neuroscience 75:99-109.

Ouanounou A, Zhang L, Charlton MP, Carlen PL (1999) Differential modulation of synaptic transmission by calcium chelators in young and aged hippocampal CA1 neurons: evidence for altered calcium homeostasis in aging. J Neurosci 19:906-915.

Peters JH, McDougall SJ, Fawley JA, Smith SM, Andresen MC (2010) Primary afferent activation of thermosensitive TRPV1 triggers asynchronous glutamate release at central neurons. Neuron 65:657-669.

Pethig R, Kuhn M, Payne R, Adler E, Chen TH, Jaffe LF (1989) On the dissociation constants of BAPTA-type calcium buffers. Cell Calcium 10:491-498.

Phillips CG, Harnett MT, Chen W, Smith SM (2008) Calcium-sensing receptor activation depresses synaptic transmission. J Neurosci 28:12062-12070.

Reid CA, Bekkers JM, Clements JD (1998) N- and P/Q-type Ca ${ }^{2+}$ channels mediate transmitter release with a similar cooperativity at rat hippocampal autapses. J Neurosci 18:2849-2855.

Rozov A, Burnashev N, Sakmann B, Neher E (2001) Transmitter release modulation by intracellular $\mathrm{Ca}^{2+}$ buffers in facilitating and depressing nerve terminals of pyramidal cells in layer $2 / 3$ of the rat neocortex indicates a target cell-specific difference in presynaptic calcium dynamics. J Physiol 531:807-826.

Ruat M, Molliver ME, Snowman AM, Snyder SH (1995) Calcium sensing receptor: molecular cloning in rat and localization to nerve terminals. Proc Natl Acad Sci U S A 92:3161-3165.

Rusakov DA, Fine A (2003) Extracellular $\mathrm{Ca}^{2+}$ depletion contributes to fast activity-dependent modulation of synaptic transmission in the brain. Neuron 37:287-297.

Sanchez-Armass S, Blaustein MP (1987) Role of sodium-calcium exchange in regulation of intracellular calcium in nerve terminals. Am J Physiol Cell Physiol 252:C595-C603.

Sara Y, Virmani T, Deák F, Liu X, Kavalali ET (2005) An isolated pool of vesicles recycles at rest and drives spontaneous neurotransmission. Neuron 45:563-573.

Schipke CG, Ohlemeyer C, Matyash M, Nolte C, Kettenmann H, Kirchhoff F (2001) Astrocytes of the mouse neocortex express functional $N$-methylD-aspartate receptors. FASEB J 15:1270-1272.

Schneggenburger R, Neher E (2000) Intracellular calcium dependence of transmitter release rates at a fast central synapse. Nature 406:889-893.

Shahrezaei V, Cao A, Delaney KR (2006) $\mathrm{Ca}^{2+}$ from one or two channels controls fusion of a single vesicle at the frog neuromuscular junction. J Neurosci 26:13240-13249.

Sharma G, Vijayaraghavan S (2003) Modulation of presynaptic store calcium induces release of glutamate and postsynaptic firing. Neuron 38:929-939.

Smith SM, Bergsman JB, Harata NC, Scheller RH, Tsien RW (2004) Recordings from single neocortical nerve terminals reveal a nonselective cation channel activated by decreases in extracellular calcium. Neuron 41:243-256.

Smith SM, Renden R, von Gersdorff H (2008) Synaptic vesicle endocytosis: fast and slow modes of membrane retrieval. Trends Neurosci 31:559-568.

Stanley EF (1993) Single calcium channels and acetylcholine release at a presynaptic nerve terminal. Neuron 11:1007-1011.

Sun J, Pang ZP, Qin D, Fahim AT, Adachi R, Südhof TC (2007) A dual$\mathrm{Ca}^{2+}$-sensor model for neurotransmitter release in a central synapse. Nature 450:676-682.

Tabata T, Kano M (2004) Calcium dependence of native metabotropic glutamate receptor signaling in central neurons. Mol Neurobiol 29:261-270.

Virmani T, Ertunc M, Sara Y, Mozhayeva M, Kavalali ET (2005) Phorbol esters target the activity-dependent recycling pool and spare spontaneous vesicle recycling. J Neurosci 25:10922-10929.

Vizard TN, O'Keeffe GW, Gutierrez H, Kos CH, Riccardi D, Davies AM (2008) Regulation of axonal and dendritic growth by the extracellular calcium-sensing receptor. Nat Neurosci 11:285-291.

Vyleta NP, Smith SM (2008) Fast inhibition of glutamate-activated currents by caffeine. PLoS ONE 3:e3155.

Wang X, Lundblad J, Smith SM (2009) Familial hypocalciuric hypercalcemia: reduced affinity of calcium sensing-receptor heterodimers underlies impaired receptor function. In: FEPS 2009, p P189. Ljubljana, Slovenia. 
Wang Y, Awumey EK, Chatterjee PK, Somasundaram C, Bian K, Rogers KV, Dunn C, Bukoski RD (2003) Molecular cloning and characterization of a rat sensory nerve $\mathrm{Ca}^{2+}$-sensing receptor. Am J Physiol Cell Physiol 285:C64-C75.

Watano T, Kimura J, Morita T, Nakanishi H (1996) A novel antagonist, No. 7943 , of the $\mathrm{Na}^{+} / \mathrm{Ca}^{2+}$ exchange current in guinea-pig cardiac ventricular cells. Br J Pharmacol 119:555-563.

Weirda KD, Toonen RF, de Wit H, Brussaard AB, Verhage M (2007) Interdependence of PKC-dependent and PKC-independent pathways for presynaptic plasticity. Neuron 54:275-290.

Wellendorph P, Bräuner-Osborne H (2004) Molecular cloning, expression, and sequence analysis of GPRC6A, a novel family C G-protein-coupled receptor. Gene 335:37-46.

Wheeler DB, Randall A, Tsien RW (1994) Roles of N-type and Q-type Ca ${ }^{2+}$ channels in supporting hippocampal synaptic transmission. Science 264:107-111.
Xiong Z, Lu WY, MacDonald JF (1997) Extracellular calcium sensed by a novel cation channel in hippocampal neurons. Proc Natl Acad Sci U S A 94:7012-7017.

Xu J, Pang ZP, Shin OH, Südhof TC (2009) Synaptotagmin-1 functions as a $\mathrm{Ca}^{2+}$ sensor for spontaneous release. Nat Neurosci 12:759-766.

Yamasaki M, Hashimoto K, Kano M (2006) Miniature synaptic events elicited by presynaptic $\mathrm{Ca}^{2+}$ rise are selectively suppressed by cannabinoid receptor activation in cerebellar Purkinje cells. J Neurosci 26:86-95.

Yang X, Kaeser-Woo YJ, Pang ZP, Xu W, Südhof TC (2010) Complexin clamps asynchronous release by blocking a secondary $\mathrm{Ca}(2+)$ sensor via its accessory alpha helix. Neuron 68:907-920.

Yu Y, Maureira C, Liu X, McCormick D (2010) P/Q and N channels control baseline and spike-triggered calcium levels in neocortical axons and synaptic boutons. J Neurosci 30:11858-11869. 